\title{
A Treasure of Bioactive Compounds from the Deep Sea
}

\author{
Assunta Saide ${ }^{\dagger}$, Chiara Lauritano $*,+(D)$ and Adrianna Ianora \\ Marine Biotechnology Department, Stazione Zoologica Anton Dohrn, Villa Comunale, 80121 Napoli, Italy; \\ assunta.saide@szn.it (A.S.); adrianna.ianora@szn.it (A.I.) \\ * Correspondence: chiara.lauritano@szn.it; Tel.: +39-0815833221 \\ + These authors contributed equally to this work.
}

Citation: Saide, A.; Lauritano, C.;

Ianora, A. A Treasure of Bioactive

Compounds from the Deep Sea.

Biomedicines 2021, 9, 1556.

https://doi.org/10.3390/

biomedicines 9111556

Academic Editor:

Raphael Mechoulam

Received: 13 September 2021

Accepted: 21 October 2021

Published: 28 October 2021

Publisher's Note: MDPI stays neutral with regard to jurisdictional claims in published maps and institutional affiliations.

Abstract: The deep-sea environment is a unique, challenging extreme habitat where species have had to adapt to the absence of light, low levels of oxygen, high pressure and little food. In order to survive such harsh conditions, these organisms have evolved different biochemical and physiological features that often have no other equivalent in terrestrial habitats. Recent analyses have highlighted how the deep sea is one of the most diverse and species-rich habitats on the planet but less explored compared to more accessible sites. Because of their adaptation to this extreme environment, deep-sea species have the potential to produce novel secondary metabolites with potent biological activities. Recent advances in sampling and novel techniques in microorganism culturing and chemical isolation have promoted the discovery of bioactive agents from deep-sea organisms. However, reports of natural products derived from deep-sea species are still scarce, probably because of the difficulty in accessing deep-sea samples, sampling costs and the difficulty in culturing deep-sea organisms. In this review, we give an overview of the potential treasure represented by metabolites produced by deep marine species and their bioactivities for the treatment and prevention of various human pathologies.

Keywords: marine organisms; bioactivities; human health; drug discovery; marine biotechnology

\section{Introduction}

Over the past 50 years, approximately 30,000 marine natural products (MNPs) have been reported from marine flora and fauna, with less than $2 \%$ of these derived from deepwater marine organisms (https:/ / pubs.rsc.org/marinlit, accessed on 27 August 2021 and the work in [1]). According to the literature, those considered as "deep environments" are variable, ranging from $10 \mathrm{~m}$ to thousands of meters. In the current study, we consider the deep sea as the part of the ocean below the $200 \mathrm{~m}$ depth and representing the largest and least explored biome on Earth [2]. Less than $<0.0001 \%$ of the deep ocean has been investigated so far and, contrary to past hypotheses of it being food-poor, metabolically inactive and composing a minor component of global carbon cycles, population complex spatial structures and widespread symbioses have been observed in the deep sea [3-5]. For many years, the difficulty to reach the bottom of the ocean has been the main issue for studying deep-sea life. Thanks to improved acoustic technology and improved access by Remotely Operated Vehicles (ROV) and submersibles, the deep-ocean environment has become more accessible, revealing the presence of biological activity in many deep-sea species [6].

The number of known marine species is $~ 250,000$ [1] and several recent projects have helped and are helping in discovering new species by better exploring the world's oceans, including deep and cold extreme environments (e.g., the Census of Marine Life (http: / / www.coml.org/index.html; accessed on 7 October 2021), EUROFLEETS2 funded Project PharmaDeep (https:/ / www.eurofleets.eu/access / previous-calls/eurofleets2-regional-2call-results/eurofleets2-funded-project-pharmadeep-results/; accessed on 7 October 2021) and Tara Oceans and Tara Oceans Polar Circle expeditions (https: / / oceans.taraexpeditions. $\mathrm{org} / \mathrm{en} / \mathrm{m} /$ about-tara/les-expeditions/tara-oceans/; accessed on 7 October 2021). These projects focused on assessing the diversity, distribution, and abundance of marine life, 
are revealing that the total number of marine species worldwide may reach hundreds of millions [1].

Searching the available literature in the PubMed database, there is a clear recent increasing trend in the number of publications in drug discovery from marine organisms and from deep-sea species (search filters used were the word "marine" and "natural products" in "all fields" and "deep", "marine" and "natural products" in "all fields", respectively; Figure 1). Interestingly, whereas the percentage of deep marine natural products papers was approximately $0.7-2.4 \%$ of the total publications on marine natural products until 2020, as of 2021 this percentage has increased to $4.55 \%$ denoting a very recent increasing interest in deep-sea compounds. At present, 135,828 patents related to marine natural products are available (by searching for "marine natural products patents" on https: / / patents.google.com/?q=marine+natural+products\&type=PATENT\&dups=language; accessed on 7 October 2021). Marine drug discovery is still considered a "new" research field as shown by the huge difference in the number of publications (Figure 1a,b). In 2020, only $4 \%$ of the publications on natural products were related to MNPs. At present, over $400,000 \mathrm{NPs}$ are known and new compounds are being discovered every year $[7,8]$, while $\sim 30,000(7.5 \%$ of total NP) are the number of MNPs identified to date since the first report of a biologically active MNP spongothymidine in 1950 [9].

(a)
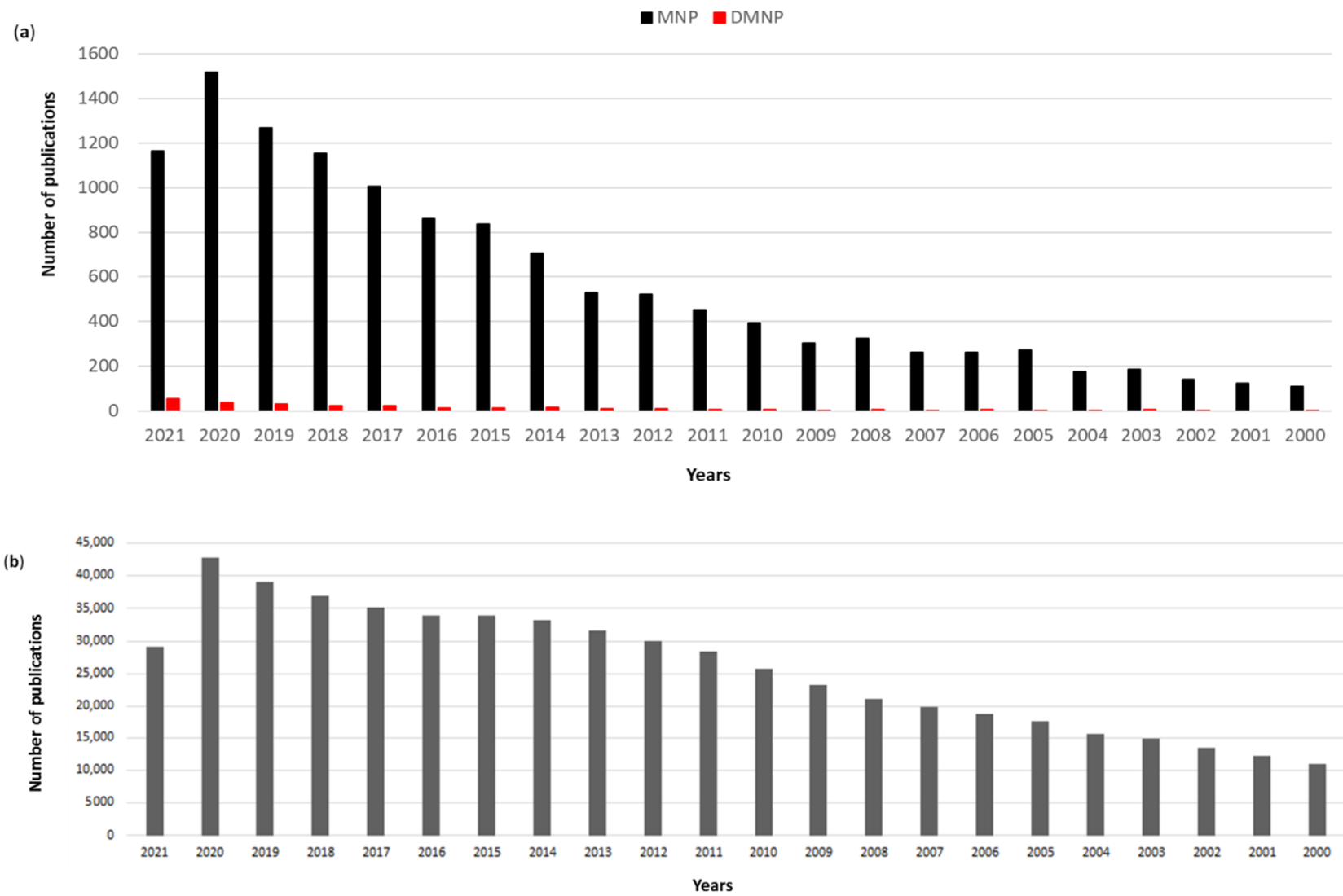

Figure 1. PubMed search results 2000-2021 by using as filters (a) the words "marine" and "natural products" for marine natural products (MNP) and "deep", "marine" and "natural products" in "all fields" for deep marine natural products (DMNP), respectively, (b) the words "natural products" in "all fields".

The increasing interest in MNPs is largely due to the novel chemical structures found in marine organisms which have greater chemical novelty with respect to their terrestrial counterparts [10]. Approximately 70\% of structural scaffolds identified in MNPs are only found in marine organisms [11]. The natural product drug discovery pipeline greatly depends on this novelty; many researchers are looking for novel marine scaffolds and, considering that the deep ocean has been less explored compared to the surface (less 
than 1000 deep MNP have been reported [1,12]), there is a higher probability to find new scaffolds in deep-sea species. In the deep-sea environment, there are a high number of single rare species, with more than half being new to science, with some taxa possessing $>95 \%$ of undescribed species. In addition, many of the species are found to exclusively inhabit the deep sea, with high levels of biodiversity extending to abyssal depths of $5000 \mathrm{~m} \mathrm{[13]}$. There are also various recent papers analyzing the characterization, cloning, expression and functional characterization of enzymes from deep-sea organisms along with investigations into the microbial diversity of deep-sea sponge-associated bacteria and other deep-sea sediment-derived microbes [14-16].

The deep sea is characterized by a pressure increase of one atmosphere (atm) for every $10 \mathrm{~m}$ increase in water depth, so pressure varies from $20 \mathrm{~atm}$ at the shelf-slope break to $>1000 \mathrm{~atm}$ in the deepest parts of ocean trenches; temperature usually drops with increasing depth reaching values around $2{ }^{\circ} \mathrm{C}$ on the abyssal plain. The oxygen concentration in bottom waters can be much less than that of the surrounding region, or even zero, depending on the balance between the rate at which oxygen is supplied and the rate at which it is consumed. Light intensity declines exponentially with depth in the water column because incident photons are absorbed or scattered, and total darkness prevails below $250 \mathrm{~m}$. Organisms inhabiting these harsh environments have developed unique strategies to adapt and survive, e.g., long lifespans, tolerance to toxic compounds at high concentrations, widespread symbiotic relationships, sound emissions, chemical signals and bioluminescence [5,17]. Their adaptation to biochemical and physiological processes may be reflected in modifications in gene regulation of primary/secondary metabolic pathways that result in the expression of novel natural products. The purpose of this review is to shed light on deep-sea metabolites and on a large number of species that produce compounds with potential activities against different human pathologies (e.g., anti-inflammatory, anticancer, antioxidant and antibacterial activities) (Figure 2). This review summarizes the state-of-the-art, and critically discusses the limits and possible advantages of drug discovery research from the deep sea.

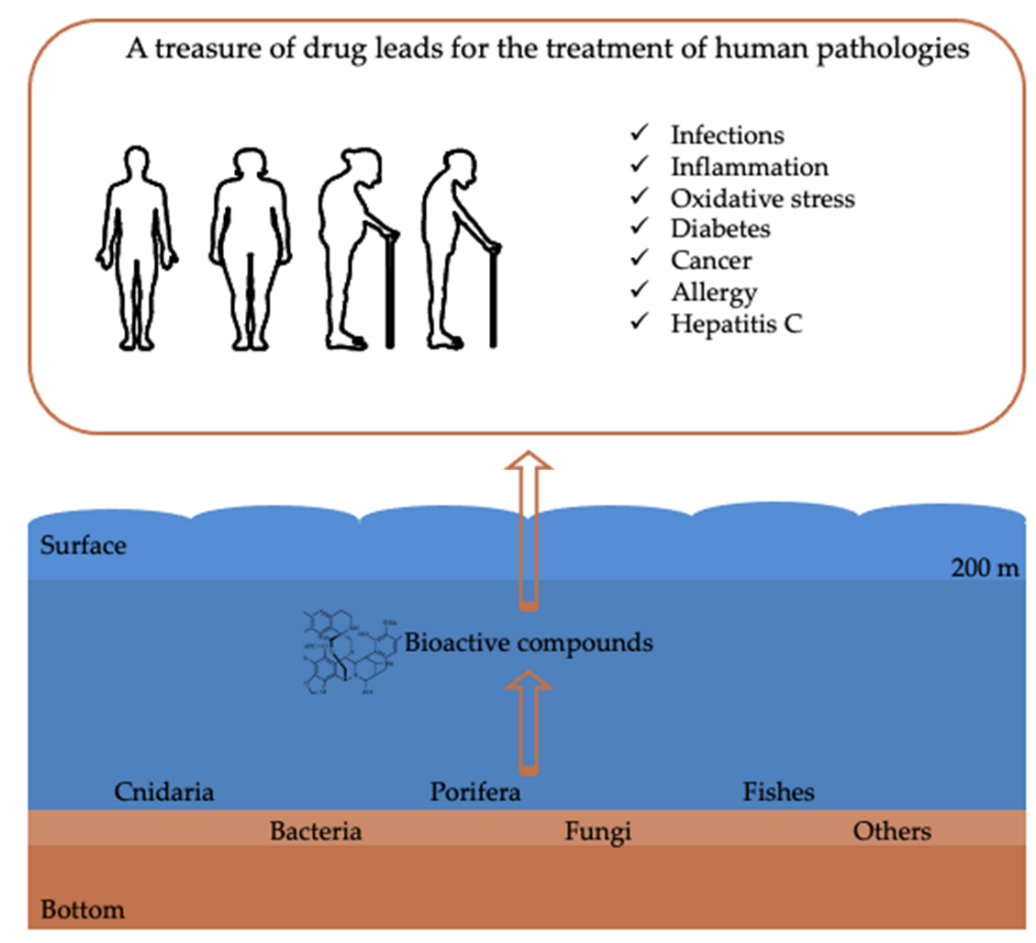

Figure 2. Schematic representation showing the main deep-sea marine organisms from which compounds with bioactivities useful for the treatment of human pathologies have been reported. Arrows indicate the flow from sampling of marine organisms from deep environments to the identification of bioactive compounds and possible applications for the treatment of human pathologies. 
Currently, there are fourteen (13 Food and Drug Administration (FDA)-approved drugs and one Australia drug approved in 2018) pharmaceutical products in clinical use, of which nine are used for different cancer treatments $\left(\right.$ Cytosar- $U^{\circledR}$, Halaven $^{\circledR}$, Adcetris ${ }^{\circledR}$,

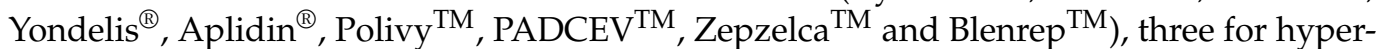
triglyceridemia (Lovaza ${ }^{\circledR}$, Vascepa ${ }^{\circledR}$ and Epanova ${ }^{\circledR}$ ), one for severe chronic pain (Prialt ${ }^{\circledR}$ ) and one as antiviral (Vira- $\mathrm{A}^{\circledR}$ ), against herpes simplex virus (https:/ / www.midwestern. edu/departments / marinepharmacology / clinical-pipeline, accessed on 12 October 2021). Their mechanisms of action and, in particular, their molecular targets are very variable. For the anticancer drugs, the molecular targets are DNA polymerase, microtubules, CD30/microtubules, minor groove of DNA, translation elongation factor 1A2 (eEF1A2), CD76b/microtubules, Nectin-4, RNA Polymerase II and B-cell maturation antigen (BCMA), for

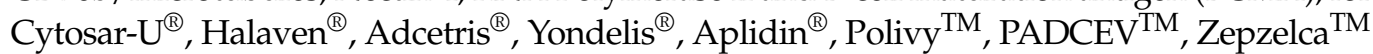
and Blenrep ${ }^{\mathrm{TM}}$, respectively. Regarding Lovaza ${ }^{\circledR}$, Vascepa ${ }^{\circledR}$ and Epanova ${ }^{\circledR}$, their molecular targets are tryglyceride-synthesizing enzymes. For Prialt ${ }^{\circledR}$, the molecular target is a N-Type Calcium channel, while for Vira-A ${ }^{\circledR}$ a viral DNA polymerase (https: / /www.midwestern. edu/departments / marinepharmacology / clinical-pipeline, accessed on 12 October 2021). Another seven marine-derived drugs are in phase I clinical trials (seven for cancer treatment and one for HIV prevention), twelve are in phase II (10 for cancer treatment, one specific for Alzheimer's disease and one for schizophrenia, Alzheimer's disease, attention deficit hyperactivity disorder, endotoxemia, sepsis and vagal activity) and four are in phase III (three against cancer and one for chronic pain). These compounds have been identified mainly from invertebrates, such as sponges, mollusks, bryozoans and ascidians, or microorganisms, mainly cyanobacteria. Cancer treatment is the most frequent field of application, maybe because these compounds have defensive roles in the natural environments. One of these derives from the deep sea (Figure 3). Ziconotide (Prialt ${ }^{\circledR}$ ) is a synthetic calcium channel-binding conotoxin isolated from the sea snail Conus magus living at depths greater than $1000 \mathrm{~m}$, used for the treatment of severe pain (it was approved by the FDA in 2004) [18]. In 2015, an anticancer agent isolated from the tunicate Ecteinascidia turbinate, sampled at $289 \mathrm{~m}$ depth, was FDA approved as trabectedin (Yondelis ${ }^{\circledR}$ ) for the treatment of soft tissue sarcomas and ovarian cancer [19]. Chemical structures of Prialt ${ }^{\circledR}$ and Yondelis ${ }^{\circledR}$ are reported in Figure 4. Sampling depth of the species from which MNPs have been isolated is not always available and it is difficult to establish how many other drugs come from the deep sea. The pre-clinical pipeline continues to supply several novel MNPs every year potentially enriching the clinical pipeline with valuable new drugs. Below, we discuss the current state of art of deep-sea species which showed bioactivities useful for the treatment of human pathologies. 
(a)

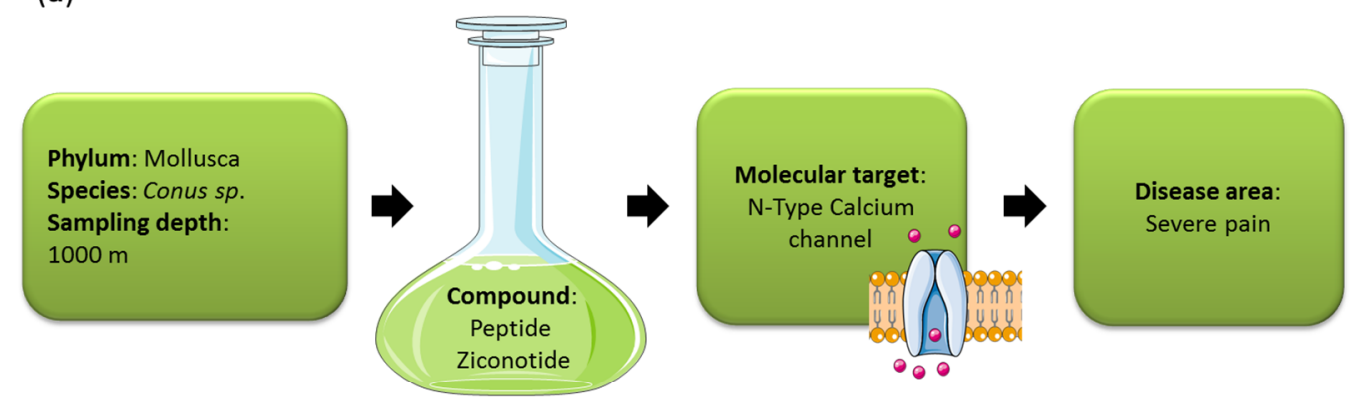

(b)

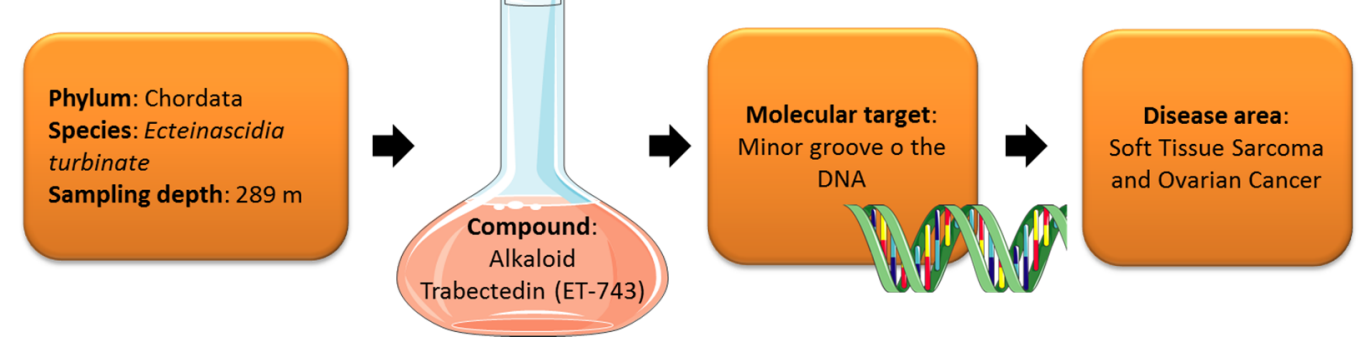

Figure 3. Two deep marine derived drugs are currently on the market: (a) Prialt ${ }^{\circledR}$ and (b) Yondelis ${ }^{\circledR}$. The figure shows species and sampling depth from which the compounds have been isolated, their molecular targets and disease areas. (a) Ziconotide (Prialt ${ }^{\circledR}$ ) was derived from the venom of a marine snail (Conus sp.) and is used for the treatment of severe pain. (b) Trabectedin, ET-743 (Yondelis ${ }^{\circledR}$ ), was derived from a marine tunicate Ecteinascidia turbinate and is used for the treatment of soft tissue sarcoma and ovarian cancer.

(a)

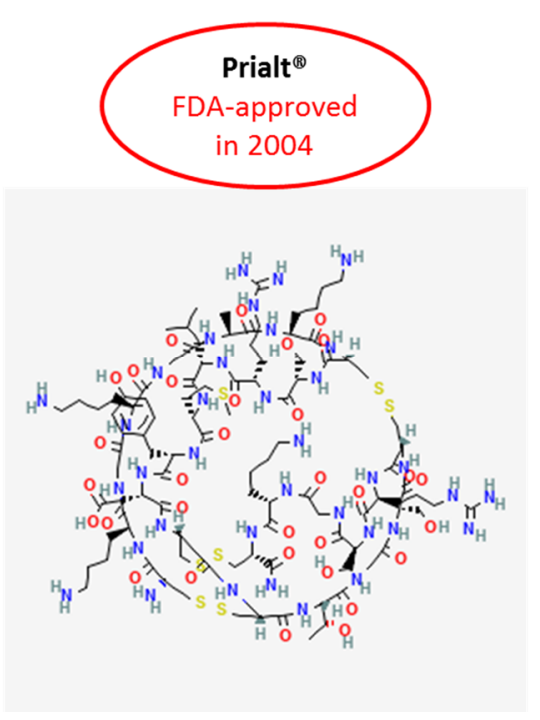

(b)

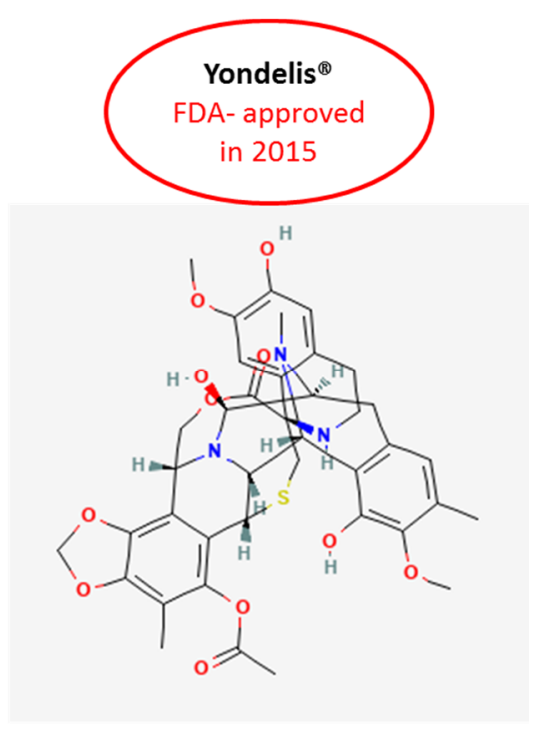

Figure 4. Chemical structures of (a) Prialt ${ }^{\circledR}$ and (b) Yondelis ${ }^{\circledR}$ FDA approved in 2004 and 2015, respectively. Chemical structures of Ziconotide (Prialt ${ }^{\circledR}$; PubChem Identifier: CID 16135415) and Trabectedin, ET-743 (Yondelis ${ }^{\circledR}$; PubChem Identifier: CID 108150), are from the public database PubChem (https: / / pubchem.ncbi.nlm.nih.gov/compound / Ziconotide\#section=2D-Structure [20] and https: / / pubchem.ncbi.nlm.nih.gov/compound/Trabectedin\#section=2D-Structure [21], both accessed on 11 October 2021). 


\section{Deep-Sea Species with Biological Activities}

\subsection{Bacteria}

Marine bacteria from deep-sea sediments have shown to be a rich source of secondary metabolites with novel structures and excellent biological activities, including antiproliferative, antimicrobial and antimalarial activities [22]. In this paragraph, we report twenty-four bacteria that have been isolated from deep-sea sediments known to produce bioactive compounds (Table 1). The genus Salinispora is an obligate seawater-requiring marine actinomycete [23] and includes Salinispora tropica, Salinispora arenicola and Salinispora pacifica. Salinispora tropica is found in tropical and subtropical marine sediments at depths up to $1100 \mathrm{~m}$ [23]. S. tropica produces the potent proteasome inhibitor salinosporamide-A, characterized by a densely functionalized $\gamma$-lactam- $\beta$-lactone bicyclic core that is responsible for its irreversible binding to the $\beta$ subunit of the 20 S proteasome. This compound displayed potent and highly selective activity in the National Cancer Institute's (NCI) 60-cell line panel with a mean $\mathrm{GI}_{50}$ value (the concentration required to achieve $50 \%$ growth inhibition) of less than $10 \mathrm{nM}$ and a greater than $4 \log \mathrm{LC}_{50}$ differential between resistant and susceptible cell lines. Better inhibition $\left(\mathrm{LC}_{50}<10 \mathrm{nM}\right)$ was observed against NCI-H226 non-small cell lung cancer, SF-539 CNS, SK-MEL-28 skin melanoma and MDA-MB-435 breast cancer [24].

Table 1. Bioactive compounds from deep-sea bacteria.

\begin{tabular}{|c|c|c|c|c|c|}
\hline $\begin{array}{l}\text { Marine } \\
\text { Organism }\end{array}$ & Compound & Activity/Experimental Model & Depth/Site & Concentrations & Ref. \\
\hline Salinispora tropica & Salinosporamide A & $\begin{array}{l}\text { Proteasome inhibitor against } \\
\text { NCI-H226-non-small cell lung } \\
\text { cancer, SF-539 CNS cancer, } \\
\text { SK-MEL-28 skin melanoma, and } \\
\text { MDA-MB-435 breast cancer. }\end{array}$ & $\begin{array}{c}1100 \mathrm{~m} \\
\text { Tropical and } \\
\text { subtropical marine } \\
\text { sediments }\end{array}$ & $\mathrm{LC}_{50}<10 \mathrm{nM}$ & [23] \\
\hline $\begin{array}{l}\text { Streptomyces sp. } \\
\text { NTK } 935\end{array}$ & Benzoxacystol 245 & $\begin{array}{c}\text { Inhibit recombinant } \\
\text { Glycogen synthase kinase } 3 \text { beta } \\
(\text { GSK-3 } \beta)\end{array}$ & $\begin{array}{c}3814 \mathrm{~m} \\
\text { Canary basin }\end{array}$ & $\mathrm{IC}_{50}=1.35 \pm 0.15 \mu \mathrm{M}$ & [25] \\
\hline $\begin{array}{l}\text { Streptomyces sp. } \\
\text { M-207 }\end{array}$ & Lobophorin $\mathrm{K}$ & $\begin{array}{c}\text { Antiproliferative activity } \\
\text { against: MiaPaca-2 and MCF7 }\end{array}$ & $\begin{array}{l}1800 \mathrm{~m} \\
\text { Lophelia pertusa }\end{array}$ & $\begin{array}{c}\mathrm{IC}_{50}=34.0 \pm 85.1 \text { and } \\
23.0 \pm 8.9 \mu \mathrm{M} \\
\text { respectively }\end{array}$ & [26] \\
\hline $\begin{array}{l}\text { Bacillus subtilis } \\
\text { B5 }\end{array}$ & $\begin{array}{l}\text { 7, 13-epoxyl- } \\
\text { macrolatin A }\end{array}$ & $\begin{array}{l}\text { Inhibitor of LPS-induced } \\
\text { inflammatory mediator } \\
\text { expression in RAW } 264.7 \text { cells }\end{array}$ & $\begin{array}{c}3000 \mathrm{~m} \\
\text { Pacific Ocean }\end{array}$ & From 50 to $40 \mu \mathrm{M}$ & [27] \\
\hline $\begin{array}{l}\text { Marianactinospora } \\
\text { thermotolerans } \\
\text { SCSIO00652 }\end{array}$ & $\begin{array}{l}\text { Marinacarbolines } \\
\text { A-D } \\
\text { 13-N-demethyl- } \\
\text { methylpendolmycin } \\
\text { Methylpendolmycin- } \\
\text { 14-O- } \alpha \text {-glucoside }\end{array}$ & $\begin{array}{l}\text { Antimalarial activity against: } \\
\text { Plasmodium falciparum }\end{array}$ & $\begin{array}{l}3865 \mathrm{~m} \\
\text { South China Sea }\end{array}$ & $\begin{array}{c}\mathrm{IC}_{50}=(\mathrm{A}) 1.92 \mu \mathrm{M} \\
\text { (C) } 3.09 \mu \mathrm{M} \text {, (D) } 5.39 \mu \mathrm{M}\end{array}$ & [28] \\
\hline $\begin{array}{c}\text { Marinactinospora } \\
\text { thermotolerans } \\
\text { SCSIO } 00652\end{array}$ & Marthiapeptide A & $\begin{array}{c}\text { Antimicrobial against: } M \text {. luteus, } \\
\text { S. aureus, } B \text {. subtilis, } B \text {. } \\
\text { thuringiensis }\end{array}$ & $\begin{array}{c}3865 \mathrm{~m} \\
\text { South China Sea }\end{array}$ & $\begin{array}{c}\mathrm{MIC}=2,8.4 \text { and } \\
2 \mu \mathrm{g} / \mathrm{mL}\end{array}$ & [29] \\
\hline $\begin{array}{c}\text { Marinactinospora } \\
\text { thermotolerans } \\
\text { SCSIO } 00652\end{array}$ & Marthiapeptide A & $\begin{array}{c}\text { Cytotoxic activity against a } \\
\text { panel of human cancer cell lines }\end{array}$ & $\begin{array}{l}3865 \mathrm{~m} \\
\text { South China Sea }\end{array}$ & $\begin{aligned} \mathrm{IC}_{50}= & \text { ranging from } 0.38 \\
& \text { to } 0.52 \mu \mathrm{M}\end{aligned}$ & [29] \\
\hline $\begin{array}{l}\text { Streptomyces } \\
\text { scopuliridis } \\
\text { SCSIOZJ } 46\end{array}$ & $\begin{array}{l}\text { Desotamide B, } \\
\text { C, D }\end{array}$ & $\begin{array}{l}\text { Antimicrobial against: S. aureus, } \\
\text { S. pneumoniae, MRSE shhs-E1 }\end{array}$ & $\begin{array}{c}3536 \mathrm{~m} \\
\text { South China Sea }\end{array}$ & $\begin{array}{c}\mathrm{MIC}=16,12.5, \text { and } \\
32 \mu \mathrm{g} / \mathrm{mL}, \text { respectively }\end{array}$ & [30] \\
\hline $\begin{array}{l}\text { Streptomyces } \\
\text { drozdowiczii } \\
\text { SCSIO10141 }\end{array}$ & $\begin{array}{l}\text { Marfomycins A, } \\
\text { B, E }\end{array}$ & Antimicrobial against: $M$. luteus & $\begin{array}{l}1396 \mathrm{~m} \\
\text { South China Sea }\end{array}$ & $\begin{array}{c}\mathrm{MIC}=0.25,4, \text { and } \\
4 \mu \mathrm{g} / \mathrm{mL}, \text { respectively }\end{array}$ & [31] \\
\hline
\end{tabular}


Table 1. Cont

\begin{tabular}{|c|c|c|c|c|c|}
\hline Marine Organism & Compound & Activity/Experimental Model & Depth/Site & Concentrations & Ref. \\
\hline $\begin{array}{l}\text { Streptomyces sp. } \\
\text { SCSIO } 01127\end{array}$ & Lobophorin F & $\begin{array}{c}\text { Antimicrobial against: } \text { S. aureus, } \\
\text { E. faecalis }\end{array}$ & $\begin{array}{l}1350 \mathrm{~m} \\
\text { South China } \\
\text { Sea }\end{array}$ & $\mathrm{MIC}=8 \mu \mathrm{g} / \mathrm{mL}$ for both & [32] \\
\hline $\begin{array}{l}\text { Streptomyces sp. } \\
\text { 12A35 }\end{array}$ & Lobophorin $\mathrm{H}$ & Antimicrobial against: B. subtilis & $\begin{array}{l}2134 \mathrm{~m} \\
\text { South China } \\
\text { Sea }\end{array}$ & $\mathrm{MIC}=3.13 \mu \mathrm{g} / \mathrm{mL}$ & [33] \\
\hline $\begin{array}{l}\text { Verrucosispora sp. } \\
\quad \text { AB 18-032 }\end{array}$ & Abyssomicin C & $\begin{array}{l}\text { Antimicrobial against: MRSA, } \\
\quad \text { vancomycin resistant } \\
\text { Enterococcus faecium, S. aureus }\end{array}$ & $\begin{array}{c}289 \mathrm{~m} \\
\text { Japanese Sea }\end{array}$ & $\begin{array}{c}\mathrm{MIC}=4 \mu \mathrm{g} / \mathrm{mL} \text { and } \\
13 \mu \mathrm{g} / \mathrm{mL}\end{array}$ & [34] \\
\hline $\begin{array}{l}\text { Streptomyces niveus } \\
\text { SCSIO3406 }\end{array}$ & $\begin{array}{l}\text { Marfuraquinocins } \\
\qquad \text { A, C, D }\end{array}$ & $\begin{array}{c}\text { Antimicrobial against: S. aureus, } \\
\text { MRSE shhs-E1 }\end{array}$ & $\begin{array}{l}3536 \mathrm{~m} \\
\text { South China } \\
\text { Sea }\end{array}$ & $\mathrm{MIC}=8 \mu \mathrm{g} / \mathrm{mL}$ & [35] \\
\hline $\begin{array}{l}\text { Micromonospora } \\
\text { matsumotoense } \\
\text { M-412 }\end{array}$ & Paulomycin G & $\begin{array}{l}\text { Antimicrobial against: } \text { E. coli } \\
\text { strains MB5746 and MRSA }\end{array}$ & $\begin{array}{c}2000 \mathrm{~m} \\
\text { Cantabrian Sea } \\
\text { sediments }\end{array}$ & $\begin{array}{c}\mathrm{MIC}_{90}=4.5 \text { and } \\
50 \mu \mathrm{g} / \mathrm{mL} \text {, respectively }\end{array}$ & [36] \\
\hline $\begin{array}{l}\text { Micromonospora } \\
\text { matsumotoense } \\
\text { M-412 }\end{array}$ & Paulomycin G & $\begin{array}{c}\text { Antiproliferative against } \\
\text { HepG2, MCF7, MiaPaca-2. }\end{array}$ & $\begin{array}{l}2000 \mathrm{~m} \\
\text { Cantabrian Sea } \\
\text { sediments }\end{array}$ & $\begin{array}{c}\mathrm{IC}_{50}=4.30 \pm 0.42 \mu \mathrm{M} \\
1.58 \pm 0.12 \mu \mathrm{M} \\
2.70 \pm 0.25 \mu \mathrm{M} \\
\text { respectively }\end{array}$ & [36] \\
\hline Bacillus subtilis & $\begin{array}{l}\text { Lipoamicoumacins } \\
\text { A-D, bacilosarcin } \\
\text { analogue and six } \\
\text { amicoumacins }\end{array}$ & $\begin{array}{l}\text { Cytotoxicity against HeLa cells } \\
\text { and antibacterial activity } \\
\text { against B. subtilis, S. aureus and } \\
\text { Laribacter hongkongensis }\end{array}$ & $\begin{array}{l}1000 \mathrm{~m} \\
\text { Red Sea }\end{array}$ & - & [37] \\
\hline $\begin{array}{l}\text { Dermacoccus abyssi } \\
\text { sp. }\end{array}$ & $\begin{array}{l}\text { Dermacozines F } \\
\text { and } G\end{array}$ & $\begin{array}{l}\text { Cytotoxic activity against the } \\
\text { leukaemia cell line K562 }\end{array}$ & $\begin{array}{l}10,898 \mathrm{~m} \\
\text { Mariana } \\
\text { Trench } \\
\text { sediment }\end{array}$ & $\begin{array}{l}\mathrm{IC}_{50} \text { values of } \\
9 \text { and } 7 \mu \mathrm{M}\end{array}$ & [38] \\
\hline $\begin{array}{l}\text { Pseudonocardia sp. } \\
\quad \text { SCSIO } 01299\end{array}$ & $\begin{array}{l}\text { Pseudonocardians } \\
\text { A-C }\end{array}$ & $\begin{array}{c}\text { Cytotoxic activity against } \\
\text { SF-268, MCF-7 and NCI-H460 }\end{array}$ & $\begin{array}{l}3258 \mathrm{~m} \\
\text { South China } \\
\quad \text { Sea }\end{array}$ & $\begin{array}{c}\mathrm{IC}_{50} \text { from } \\
0.01 \text { to } 0.21 \mu \mathrm{M}\end{array}$ & [39] \\
\hline $\begin{array}{l}\text { Pseudonocardia sp. } \\
\quad \text { SCSIO } 01299\end{array}$ & $\begin{array}{l}\text { Pseudonocardians } \\
\text { A-C }\end{array}$ & $\begin{array}{c}\text { Antibacterial activities against } S \text {. } \\
\text { aureus ATCC 29213, Enterococcus } \\
\text { faecalis ATCC 29,212 and } \\
\text { Bacillus thuringensis SCSIO BT01 }\end{array}$ & $\begin{array}{l}3258 \mathrm{~m} \\
\text { South China } \\
\text { Sea }\end{array}$ & $\begin{array}{l}\text { MIC values of } \\
1-4 \mu \mathrm{g} \mathrm{mL}^{-1}\end{array}$ & [39] \\
\hline $\begin{array}{l}\text { Streptomyces } \\
\text { lusitanus }\end{array}$ & Grincamycin A-E & $\begin{array}{l}\text { Cytotoxic activity against } \\
\text { HepG2, SW-1990, HeLa, } \\
\text { NCI-H460, MCF-7 and B16 }\end{array}$ & $\begin{array}{l}3370 \mathrm{~m} \\
\text { South China } \\
\text { Sea }\end{array}$ & $\mathrm{IC}_{50}$ from 1.1 to $31 \mu \mathrm{M}$ & [40] \\
\hline $\begin{array}{l}\text { Streptomyces sp. } \\
\text { SCSIO } 03032\end{array}$ & $\begin{array}{l}\text { Spiroindimicins } B, \\
\text { C and D }\end{array}$ & $\begin{array}{l}\text { Cytotoxic activity against } \\
\text { several cancer cell lines }\end{array}$ & $\begin{array}{c}3412 \mathrm{~m} \\
\text { Indian Ocean }\end{array}$ & $\begin{array}{c}\mathrm{IC}_{50} \text { from } 4 \text { to } 12 \mu \mathrm{g} \\
\mathrm{mL}^{-1} \text { for Spiroindimicin } \\
\mathrm{B}_{,} \mathrm{IC}_{50} \text { from } 6 \text { to } \\
15 \mu \mathrm{g} \mathrm{mL^{-1 }} \text { for } \\
\text { Spiroindimicin } \mathrm{C}_{,}-\end{array}$ & [41] \\
\hline $\begin{array}{l}\text { Streptomyces sp. } \\
\text { NTK } 937\end{array}$ & Caboxamycin & $\begin{array}{l}\text { Inhibitory activity against } \\
\text { Gram-positive bacteria, } B \text {. } \\
\text { subtilis, S. lentus, S. epidermidis, } \\
\text { the yeast Candida glabrata, the } \\
\text { phytopathogenic bacteria } \\
\text { Xanthomonas campestris and } \\
\text { Ralstonia solanacearum, and } \\
\text { against the opportunistic } \\
\text { pathogen Staphylococcus } \\
\text { epidermidis }\end{array}$ & $\begin{array}{c}3814 \mathrm{~m} \\
\text { Atlantic Ocean }\end{array}$ & $\begin{array}{c}\mathrm{IC}_{50}=8 \mu \mathrm{M}, 20 \mu \mathrm{M} \\
43 \mu \mathrm{M}, 117 \mu \mathrm{M}, 43 \mu \mathrm{M}, \\
176 \mu \mathrm{M} \text { and } 43 \mu \mathrm{M} \\
\text { respectively }\end{array}$ & [42] \\
\hline
\end{tabular}


Table 1. Cont.

\begin{tabular}{|c|c|c|c|c|c|}
\hline Marine Organism & Compound & Activity/Experimental Model & Depth/Site & Concentrations & Ref. \\
\hline $\begin{array}{l}\text { Streptomyces sp. } \\
\text { NTK } 937\end{array}$ & Caboxamycin & $\begin{array}{c}\text { Cytotoxic activity towards } \\
\text { gastric adenocarcinoma (AGS), } \\
\text { HepG2 and MCF-7. }\end{array}$ & $\begin{array}{l}3814 \mathrm{~m} \\
\text { Atlantic Ocean }\end{array}$ & $\mathrm{IC}_{50}=28.6-29.4 \mu \mathrm{M}$ & [42] \\
\hline $\begin{array}{l}\text { Streptomyces sp. } \\
\text { NTK } 937\end{array}$ & Caboxamycin & $\begin{array}{l}\text { Weak inhibitor of bovine brain } \\
\text { phosphodiesterase }\end{array}$ & $\begin{array}{c}3814 \mathrm{~m} \\
\text { Atlantic Ocean }\end{array}$ & $\mathrm{IC}_{50}=148 \mu \mathrm{M}$ & [42] \\
\hline Nocardiopsis alba & Diketopiperazines & $\begin{array}{l}\text { Cytotoxicity against MCF7 and } \\
\text { SF-268 human cancer cell lines }\end{array}$ & $\begin{array}{l}1000 \mathrm{~m} \\
\text { Indian Ocean }\end{array}$ & $\begin{array}{c}\mathrm{IC}_{50}=4.6 \text { and } 12.7 \mu \mathrm{M}, \\
\text { respectively }\end{array}$ & [43] \\
\hline $\begin{array}{l}\text { Bacillus pumilus } \\
\text { MB } 40\end{array}$ & $\begin{array}{l}\text { Bis (2-ethylhexyl) } \\
\text { phthalate (BEHP) }\end{array}$ & $\begin{array}{l}\text { Antiproliferative effect against } \\
\text { human erythroleukemic K562 } \\
\text { through apoptosis. }\end{array}$ & $\begin{array}{l}1000 \mathrm{~m} \\
\text { Red Sea }\end{array}$ & $\mathrm{IC}_{50}=21 \mu \mathrm{M}$ & [44] \\
\hline
\end{tabular}

Abbreviations are: $\mathrm{LC}_{50}$ for lethal concentration; MIC for minimum inhibitory concentration; $\mathrm{IC}_{50}$ for the concentration ( $\mu \mathrm{g} / \mathrm{mL}$ ) inducing $50 \%$ loss of cell viability; NCI-H226 for non-small cell lung cancer; SF-539 for human glioblastoma cell line; SK-MEL-28 for skin melanoma cell line; MDA-MB-435 breast cancer cell line; HepG2 for Hepatocellular carcinoma; MiaPaca-2 for human pancreatic carcinoma; MCF-7 for breast cancer; "-" means that there is a lack of corresponding information.

Nachtigall et al. [25] identified benzoxacystol 245 from the bacterium Streptomyces sp. strain NTK 935 (sampling depth $3814 \mathrm{~m}$ ), that is the first benzoxazine reported to have an inhibitory activity against glycogen synthase kinase $3 \beta$ (GSK-3 $\beta$ ) and inhibited the recombinant enzyme in an in vitro enzyme activity assay with an $\mathrm{IC}_{50}$ value of $1.35 \pm 0.15 \mu \mathrm{M}$ (Table 1). GSK-3 $\beta$ is a key regulator of numerous signaling pathways and has emerged as a prominent target for the treatment of Alzheimer's disease and type 2 diabetes. In addition, benzoxacystol 245 exhibited weak antiproliferative activity against mouse fibroblast NIH-3T3 cells, inhibiting 18\% cell growth at a concentration of $50 \mu \mathrm{M}$.

For the family lobophorin, Braña et al. [26] isolated a new natural product designated as lobophorin K, from the marine actinobacterium Streptomyces sp. M-207, previously isolated from the cold-water coral Lophelia pertusa collected at $1800 \mathrm{~m}$. This new natural product displayed cytotoxic activity against two human tumor cell lines, pancreatic carcinoma (MiaPaca-2) and MCF-7, with $\mathrm{IC}_{50}$ values of $34.0 \pm 85.1$ and $23.0 \pm 8.9$, respectively (Table 1).

A novel compound, named 7,13-epoxyl-macrolatin A, was isolated from Bacillus subtilis B5 that is an inhibitor of lipopolysaccharide (LPS)-induced inflammatory mediator expression in RAW264.7 cells (macrophage cell lines) [27]. This compound was isolated from sediments collected at a depth of $3000 \mathrm{~m}$ in the Pacific Ocean and exhibited a more potent inhibitory effect on nitric oxide (NO) production and several inflammatory cytokines than the previously known macrolactins, such as macrolactin A and analogues. This compound also inhibited the mRNA expression of the inducible nitric oxide synthase (iNOS), interleukin-1 $\beta$ and interleukin-6 in LPS-stimulated RAW 264.7 cells.

In 2011, Huang et al. [28] isolated different compounds from Marianactinospora thermotolerans SCSIO00652 (sampling depth $3865 \mathrm{~m}$ ), named marinacarbolines A-D, 13-N-demethylmethylpendolmycin, methylpendolmycin-14-O- $\alpha$-glucoside. Huang et al. demonstrated that marinacarbolines had antimalarial activity against Plasmodium falciparum (Table 1).

Other compounds isolated from deep bacteria showed interesting antimicrobial activities. In particular, marthiapeptide A, derived from Marinactinospora thermotolerans SCSIO 00652, sampled at $3865 \mathrm{~m}$ in the South China Sea, also showed antimicrobial activity. Zhou et al. [29] showed that this compound had antimicrobial activity against Microccocus luteus, Staphilococcus aureus, Bacillococcus subtilis and Bacillococcus thuringiensis, with minimum inhibitory concentration (MIC) values of 2, 8.4 and $2 \mu \mathrm{g} / \mathrm{mL}$. Marthiapeptide A was also tested for cytotoxic activity against the human glioblastoma cell line (SF-268), the human breast adenocarcinoma cell line (MCF-7), the human lung carcinoma cell line (NCI-H460) and the human hepatocarcinoma cancer cell line (HepG2). Activity testing showed $\mathrm{IC}_{50}$ (concentration of drug required for $50 \%$ inhibition) values ranging from 0.38 to $0.52 \mu \mathrm{M}$ [29]. In 2014, Song et al. [30] isolated from the deep-sea organism Streptomyces 
scopuliridis SCSIOZI 46 (sampling depth $3536 \mathrm{~m}$ ) the compounds desotamides. In particular, desotamide B, C and D showed antimicrobial activity against S. aureus, S. pneumoniae and methicillin-resistant Staphylococcus epidermidis (MRSE) with a MIC value of 16, 12.5 and $32 \mu \mathrm{g} / \mathrm{mL}$, respectively. Zhou et al. [31] isolated from the bacterium Streptomyces drozdowiczii SCSIO10141 (sampling depth $1396 \mathrm{~m}$ ) marfomycins A, B and E, which also showed antimicrobial activity against $M$. luteus with MIC values of $0.25,4$, and $4 \mu \mathrm{g} / \mathrm{mL}$, respectively. In 2011, Niu et al. [32] collected Streptomyces sp. SCSIO 01127 from $1350 \mathrm{~m}$ of the South China Sea and isolated lobophorin $\mathrm{F}$ that showed antimicrobial activity against S. aureus and Enterococcus faecalis with MIC values of $8 \mu \mathrm{g} / \mathrm{mL}$ (for both). According to Pan et al. [33], lobophorin H isolated from Streptomyces sp. 12A35 (sampling depth $2134 \mathrm{~m}$ ) showed antimicrobial activity against B. subtilis with a MIC value of $3.13 \mu \mathrm{g} / \mathrm{mL}$. Bister et al. [34] collected from the Japanese Sea the Verrucosispora sp. AB 18-032 (sampling depth $289 \mathrm{~m}$ ) and isolated abyssomicin $C$ that showed antimicrobial activity against MRSA, vancomycin resistant Enterococcus faecium and S. aureus with a MIC value of $4 \mu \mathrm{g} / \mathrm{mL}$. Song et al. [35] collected the bacterium Streptomyces niveus SCSIO3406 from $3536 \mathrm{~m}$ of the South China Sea and isolated the compounds marfuraquinocins A, C and D. These molecules showed antimicrobial activity against S.aureus and MRSE shhs-E1 with a MIC value of $8 \mu \mathrm{g} / \mathrm{mL}$ (for both). Sarmiento-Vizcaíno et al. [36] isolated a novel natural product of the paulomycin family, designated as paulomycin $\mathrm{G}$, obtained from the marine strain Micromonospora matsumotoense M-412, collected from Cantabrian Sea sediments at $2000 \mathrm{~m}$ depth. Paulomycin G showed antimicrobial activity against E. coli strains MB5746 and MRSA with a minimum concentration at which $90 \%$ of the isolates were inhibited ( MIC $_{90}$ ) values of 4.5 and $50 \mu \mathrm{g} / \mathrm{mL}$, respectively [36]. Paulomycin G showed a strong cytotoxic activity against MCF-7, MiaPaca-2, and HepG2 cancer cell lines (Table 1). The Bacillus subtilis isolated from deep-sea sediments collected at a depth of $1000 \mathrm{~m}$ in the Red Sea was found to yield four novel amicoumacins, lipoamicoumacins A-D [37], and one new bacilosarcin analogue along with six known amicoumacins. Two of the known amidecontaining amicoumacin and bacilosarcin analogues were found to display both significant cytotoxicity against HeLa cells and antibacterial activity against B. subtilis, S. aureus and Laribacter hongkongensis. Dermacozines A-G were reported from the actinobacteria Dermacoccus abyssi sp. nov., strains MT1.1 and MT1.2, isolated from Mariana Trench sediments collected at a depth of 10,898 m. Dermacozines F and G displayed moderate cytotoxic activity against the leukemia cell line $\mathrm{K} 562$ with $\mathrm{IC}_{50}$ values of 9 and $7 \mu \mathrm{M}$, respectively, while dermacozine $C$ also exhibited high radical scavenger activity with an $\mathrm{IC}_{50}$ value of $8.4 \mu \mathrm{M}$ [38]. The actinobacterium Pseudonocardia sp. strain (SCSIO 01299), recovered from deep-sea sediments obtained at $3258 \mathrm{~m}$ depth in the South China Sea, yielded three new diazaanthraquinone derivatives, pseudonocardians $\mathrm{A}-\mathrm{C}$; these compounds exhibited cytotoxic activity against three tumor cell lines SF-268 (central nervous system cancer), MCF-7 (breast cancer) and NCI-H460 (lung cancer) with $\mathrm{IC}_{50}$ values ranging between 0.01 and $0.21 \mu \mathrm{M}$. The compounds also showed antibacterial activities against $S$. aureus ATCC 29213, Enterococcus faecalis ATCC 29212 and Bacillus thuringensis SCSIO BT01, with MIC values of 1-4 $\mu \mathrm{g} \mathrm{mL}^{-1}$ [39] and are the subject of a patent (CN102351859A). The actinobacteria Streptomyces lusitanus, obtained from $3370 \mathrm{~m}$ deep sediments collected in the South China Sea, provided five new C-glycoside angucycline metabolites, grincamycins B-F and a known angucycline antibiotic, grincamycin. Grincamycin A-E displayed in vitro cytotoxicities against the human cancer cell lines HepG2 (hepatocellular liver), SW-1990 (pancreatic), HeLa (epithelial carcinoma), NCI-H460 (lung) and MCF-7 (breast adenocarcinoma), and the mouse melanoma cell line (B16), with $\mathrm{IC}_{50}$ values ranging from 1.1 to $31 \mu \mathrm{M}$ [40]. A deep-sea actinobacterium collected from Streptomyces sp. SCSIO 03032, recovered from a sediment sample at $3412 \mathrm{~m}$ depth in the Indian Ocean, produced four novel bisindole alkaloids spiroindimicins $\mathrm{A}-\mathrm{D}$, together with two known compounds, lynamicins A and D. Spiroindimicins B-D with a $(5,5)$ spiro-ring displaying moderate cytotoxicities against several cancer cell lines [41]. A further Streptomyces sp. (NTK 937) recovered from an Atlantic Ocean deep-sea sediment core collected at a depth of $3814 \mathrm{~m}$, 
yielded a new benzoxazole antibiotic, caboxamycin which exhibited inhibitory activity against Gram-positive bacteria and the enzyme phosphodiesterase as well as cytotoxic activity towards gastric adenocarcinoma (AGS), hepatocellular carcinoma (HepG2) and a breast carcinoma cell line (MCF-7) [42]. Diketopiperazines, isolated from Nocardiopsis alba sampled at $>1000 \mathrm{~m}$, showed cytotoxic activity against MCF7 and SF-268 human cancer cell lines with $\mathrm{IC}_{50}$ values of 4.6 and $12.7 \mu \mathrm{M}$, respectively [43]. In 2012, Moushumi Priya and Jayachandran [44] isolated the marine Bacillus pumilus MB 40 from deep sea water column (1000 $\mathrm{m}$ depth) near Andaman and Nicobarislands (Islands, India) that produced a bioactive lead, bis(2-ethylhexyl) phthalate (BEHP). This compound activity was examined in human erythroleukemic K562 cells using the 3-(4,5-dimethylthiazol-2-yl)-2,5-diphenyltetrazolium bromide (MTT) assay and the $\mathrm{IC}_{50}$ was found to be $21 \mu \mathrm{M}$ [44]. BEHP was able to induce apoptosis involving caspase pathways, besides regulating mitochondrial enzymes.

\subsection{Fungi}

The deep-sea fungi have also been shown to produce metabolites with various possible bioactivities (such as antimicrobial, anti-inflammatory, antioxidant and anti-diabetes) and can be a potential addition to modern medicine, industry and agriculture [45]. We found twenty species of deep fungi (Table 2) which have been shown to be producers of bioactive molecules. Zhang et al. [45] investigated the diversity of fungal communities in nine different deep-sea sediments. The samples were collected at approximately $2400-4000 \mathrm{~m}$ depths during the South China Sea Open Cruise in August 2011. Twenty-seven fungal representatives were tested against marine pathogenic bacteria and two marine pathogenic fungi to examine their spectra of antimicrobial activity. The authors [45] found that some isolates belonging to the genera Aspergillus and Penicillium exhibited relatively high antibacterial and antifungal activity. The antimicrobial activities of fungal isolates were determined by a double-layer technique. Two marine pathogenic bacteria, Micrococcus luteus (ML) and Pseudoalteromonas piscida (PP), and two marine pathogenic fungi, Aspergillus versicolor (AV) and Aspergillus sydowii (AS), were used as the indicator microorganisms for the double-layer assay [45]. Aspergillus fischeri FS452 was isolated from deep-sea sludge in the Indian Ocean at $3000 \mathrm{~m}$ depth. Fiscpropionates A-D obtained from this fungus exhibited significant inhibitory activities against Mycobacterium tuberculosis protein-tyrosine phosphatase $\mathrm{B}$, an important virulence factor. Fiscpropionates $A$ and $C$ were comparatively effective, with $\mathrm{IC}_{50}$ values of 5.1 and $4 \mu \mathrm{M}$, respectively [46]. The emerixanthones A-D isolated from the deep-sea fungus Emericella sp. SCSIO05240 (sampling depth at 3258) showed antibacterial activity against Escherichia coli, Klebsiella pneumoniae, Staphilococcus aureus, Enterococcus faecalis, Acinetobacter baumannii and Aeromonas hydrophila [47].

Table 2. Bioactive compounds from deep-sea fungi.

\begin{tabular}{|c|c|c|c|c|c|}
\hline $\begin{array}{l}\text { Marine } \\
\text { Organism }\end{array}$ & Compounds & Activity/Experimental Model & Depth/Site & Concentrations & Ref. \\
\hline $\begin{array}{l}\text { Aspergillus } \\
\text { fischeri } \\
\text { FS452 }\end{array}$ & $\begin{array}{c}\text { Fiscpropionates A } \\
\text { and C }\end{array}$ & $\begin{array}{c}\text { Inhibitory activities against } \\
\text { Mycobacterium tuberculosis } \\
\text { protein-tyrosine phosphatase B }\end{array}$ & $\begin{array}{c}3000 \mathrm{~m} \\
\text { Indian Ocean }\end{array}$ & $\begin{array}{c}\mathrm{IC}_{50}=5.1 \text { and } 4 \mu \mathrm{M}, \\
\text { respectively }\end{array}$ & [46] \\
\hline $\begin{array}{l}\text { Emericella sp. } \\
\text { SCSIO05240 }\end{array}$ & $\begin{array}{c}\text { Emerixanthones A } \\
\text { and } C\end{array}$ & $\begin{array}{c}\text { Antibacterial activity against } E \text {. } \\
\text { coli, K. pneumoniae, S. aureus, } \\
\text { E.faecalis, A. Baumanni, A. } \\
\text { hydrophila }\end{array}$ & $\begin{array}{c}3258 \mathrm{~m} \\
\text { South China Sea }\end{array}$ & $\begin{array}{l}\text { Diameters of } \\
\text { inhibition zones were } \\
4-6 \mathrm{~mm}\end{array}$ & [47] \\
\hline
\end{tabular}


Table 2. Cont.

\begin{tabular}{|c|c|c|c|c|c|}
\hline $\begin{array}{l}\text { Marine } \\
\text { Organism }\end{array}$ & Compounds & Activity/Experimental Model & Depth/Site & Concentrations & Ref. \\
\hline $\begin{array}{l}\text { Emericella sp. } \\
\text { SCSIO05240 }\end{array}$ & Emerixanthone D & $\begin{array}{l}\text { Antifungal activity against } \\
\text { Fusarium sp., Penicillium sp., } \\
\text { Aspergillus niger, Rhizoctonia solani, } \\
\text { Fusariumoxy sporium } f \text {. sp. niveum, } \\
\text { Fusariumoxy sporium } f \text {. sp. } \\
\text { cucumeris }\end{array}$ & $\begin{array}{c}3258 \mathrm{~m} \\
\text { South China Sea }\end{array}$ & $\begin{array}{l}\text { Diameters of } \\
\text { inhibition zones were } \\
3-4 \mathrm{~mm}\end{array}$ & [47] \\
\hline $\begin{array}{l}\text { Penicillium } \\
\text { aculeatum } \\
\text { SD-321 }\end{array}$ & $\begin{array}{c}\text { Compound } 1 \\
\text { (peniciaculin A) } \\
\text { Compounds } 2 \\
\text { (peniciaculin B) and } \\
4(1- \\
\text { hydroxyboivinianin } \\
\text { A) } \\
\text { Compound } 6 \\
\text { (bisabolane) }\end{array}$ & $\begin{array}{c}\text { Antibacterial activity against: } \\
\text { Micrococcus luteus and Vibrio } \\
\text { alginolyticus } \\
\text { Edwardsiella tarda and Vibrio } \\
\text { harveyi } \\
\text { Staphyloccocus aureus and Vibrio } \\
\text { parahemolyticus }\end{array}$ & $\begin{array}{c}2038 \mathrm{~m} \\
\text { South China Sea }\end{array}$ & $\begin{array}{c}\mathrm{MIC}=1.0 \text { and } \\
2.0 \mu \mathrm{g} / \mathrm{mL}, \\
\text { respectively } \\
\mathrm{MIC}=8.0 \text { and } \\
4.0 \mu \mathrm{g} / \mathrm{mL}, \\
\text { respectively } \\
\mathrm{MIC}=0.5 \mu \mathrm{g} / \mathrm{mL}\end{array}$ & [48] \\
\hline $\begin{array}{l}\text { Penicillium } \\
\text { aculeatum } \\
\text { SD-321 }\end{array}$ & $\begin{array}{l}\text { Compound } 1 \\
\text { (peniciaculin A) } \\
\text { Compounds } 7 \text { and } \\
10 \text { (bisabolanes) }\end{array}$ & $\begin{array}{l}\text { Antifungal activity against: } \\
\text { Alternaria brassicae } \\
\text { Gaeumannomyces graminis }\end{array}$ & $\begin{array}{l}2038 \mathrm{~m} \\
\text { South China Sea }\end{array}$ & $\begin{array}{l}\mathrm{MIC}=0.5 \mu \mathrm{g} / \mathrm{mL} \\
\mathrm{MIC}=0.5 \mu \mathrm{g} / \mathrm{mL}\end{array}$ & [48] \\
\hline $\begin{array}{l}\text { Penicillium sp. } \\
\quad \text { F23-2 }\end{array}$ & Penycyclones A-E & $\begin{array}{l}\text { Antimicrobial activity against the } \\
\text { Gram-positive bacterium } \\
\text { Staphylococcus aureus }\end{array}$ & $\begin{array}{c}5080 \mathrm{~m} \\
\text { Jiaozhou Bay, } \\
\text { Qingdao, China }\end{array}$ & $\begin{array}{c}\mathrm{MIC}= \\
0.3 \text { to } 1.0 \mu \mathrm{g} / \mathrm{mL}\end{array}$ & [49] \\
\hline $\begin{array}{l}\text { Spiromastix sp. } \\
\text { MCCC3A00308 }\end{array}$ & $\begin{array}{l}\text { Spiromastilactones } \\
\text { A-M }\end{array}$ & $\begin{array}{l}\text { Antiviral activity against } \\
\text { influenza virus replication } \\
\text { in vitro }\end{array}$ & $\begin{array}{l}2869 \mathrm{~m} \\
\text { South Atlantic }\end{array}$ & Table 3 in the reference & [50] \\
\hline $\begin{array}{l}\text { Simplicillium } \\
\text { oblavatum } \\
\text { EIODSF } 020\end{array}$ & $\begin{array}{l}\text { Simplicilliumtide J, } \\
\text { Verlamelins A and B }\end{array}$ & $\begin{array}{l}\text { Antifungal activity against } \\
\text { Aspergillus versicolor and } \\
\text { Curvularia australiensis }\end{array}$ & $\begin{array}{l}4571 \mathrm{~m} \\
\text { East Indian } \\
\text { Ocean }\end{array}$ & $\mathrm{MIC}=50 \mu \mathrm{g} / \mathrm{mL}$ & [51] \\
\hline $\begin{array}{l}\text { Simplicillium } \\
\text { oblavatum } \\
\text { EIODSF } 020\end{array}$ & $\begin{array}{l}\text { Simplicilliumtide J, } \\
\text { Verlamelins A and B }\end{array}$ & Antiviral activity against HSV-1 & $\begin{array}{l}4571 \mathrm{~m} \\
\text { East Indian } \\
\text { Ocean }\end{array}$ & $\begin{array}{c}\mathrm{IC}_{50}=14.0,16.7 \text { and } \\
15.6 \mu \mathrm{M} / \mathrm{mL} \\
\text { respectively }\end{array}$ & [51] \\
\hline Acremonium sp. & $\begin{array}{l}\text { Acremeremophilanes } \\
\text { B and E }\end{array}$ & $\begin{array}{c}\text { Inhibitory effects towards } \\
\text { LPS-induced NO production in } \\
\text { RAW } 264.7\end{array}$ & $\begin{array}{l}2869 \mathrm{~m} \\
\text { South Atlantic } \\
\text { Ocean }\end{array}$ & $\begin{array}{c}\mathrm{EC}_{50}=8 \mu \mathrm{M} \text { and } \\
15 \mu \mathrm{M} \text {, respectively }\end{array}$ & [52] \\
\hline $\begin{array}{l}\text { Eutypella sp. } \\
\text { MCCC3A00281 }\end{array}$ & $\begin{array}{l}\text { Eutyperemophilanes } \\
\text { I and J }\end{array}$ & $\begin{array}{c}\text { Inhibitory effects towards } \\
\text { LPS-induced NO production in } \\
\text { RAW } 264.7\end{array}$ & $\begin{array}{l}5610 \mathrm{~m} \\
\text { South Atlantic } \\
\text { Ocean }\end{array}$ & $\mathrm{IC}_{50}=8.6$ and $13 \mu \mathrm{M}$ & [53] \\
\hline $\begin{array}{l}\text { Penicillium } \\
\text { chrysogenum } \\
\text { SCSIO411001 }\end{array}$ & $\begin{array}{l}\text { Trans-epoxyamides, } \\
\text { chrysamides C }\end{array}$ & $\begin{array}{l}\text { Inhibitory effects on the } \\
\text { Interleukin-17 production }\end{array}$ & $\begin{array}{c}3386 \mathrm{~m} \\
\text { Indian Ocean }\end{array}$ & $\begin{array}{c}1 \mu \mathrm{M} \text { for } 40.06 \% \text { of } \\
\text { inhibition }\end{array}$ & [54] \\
\hline $\begin{array}{l}\text { Myrothecium sp. } \\
\text { BZO-L062 }\end{array}$ & $\begin{array}{l}(-)-1 S \text {-myrothecol } \\
\text { and } \\
(+)-1 R \text {-myrothecol }\end{array}$ & $\begin{array}{l}\text { Anti-inflammatory, inhibiting NO } \\
\text { formation in LPS-treated } \\
\text { macrophage-like cells }\end{array}$ & $\begin{array}{l}2130 \mathrm{~m} \\
\text { Yongxing Island }\end{array}$ & $\begin{array}{l}\mathrm{EC}_{50}=1.20 \text { and } \\
1.41 \mu \mathrm{g} / \mathrm{mL}\end{array}$ & [55] \\
\hline $\begin{array}{l}\text { Aspergillus sp. } \\
\text { SCSIOW2 }\end{array}$ & $\begin{array}{l}\text { Cyclopenol and } \\
\text { cyclopenin }\end{array}$ & $\begin{array}{c}\text { Inhibited the LPS-induced } \\
\text { formationof nitric oxide and the } \\
\text { secretion of IL-6 in RAW } 264.7 \\
\text { cells }\end{array}$ & $\begin{array}{c}2439 \mathrm{~m} \\
\text { South China Sea }\end{array}$ & $\mathrm{IC}_{50}=50-100 \mu \mathrm{M}$ & [56] \\
\hline $\begin{array}{l}\text { Penicillium } \\
\text { chrysogenum } \\
\text { MCCC } \\
\text { 3A00292 }\end{array}$ & Cyclopenol & $\begin{array}{l}\text { Inhibition of human Bladder } \\
\text { cancer cell line BIU-87 }\end{array}$ & - & $\mathrm{IC}_{50}=8.34 \mu \mathrm{M}$ & [57] \\
\hline
\end{tabular}


Table 2. Cont.

\begin{tabular}{|c|c|c|c|c|c|}
\hline $\begin{array}{c}\text { Marine } \\
\text { Organism }\end{array}$ & Compounds & Activity/Experimental Model & Depth/Site & Concentrations & Ref. \\
\hline $\begin{array}{l}\text { Penicillium spp. } \\
\text { and Eurotium } \\
\text { sp. }\end{array}$ & $\begin{array}{l}\text { Fructigenine A, } \\
\text { cyclopenol, } \\
\text { echinulin, } \\
\text { flavoglaucin, and } \\
\text { viridicatol }\end{array}$ & $\begin{array}{l}\text { Inhibition of protein-tyrosine } \\
\text { phosphatase } 1 \mathrm{~B}\end{array}$ & $\begin{array}{l}- \\
\text { Wan Island, } \\
\text { Korea }\end{array}$ & $\begin{array}{c}\mathrm{IC}_{50}=10.7,30.0,29.4 \\
13.4, \text { and } 64.0 \mu \mathrm{M} \\
\text { respectively }\end{array}$ & {$[58]$} \\
\hline $\begin{array}{l}\text { Graphostroma } \\
\text { sp. } \\
\text { MCC3A00421 }\end{array}$ & Reticulol & $\begin{array}{l}\text { Decrease the rates of } \\
\text { degranulation and histamine } \\
\text { release in RBL-2H3 cells }\end{array}$ & $\begin{array}{c}2721 \mathrm{~m} \\
\text { Atlantic } \\
\text { hydrotermal } \\
\text { sulfide }\end{array}$ & $\begin{array}{c}\mathrm{IC}_{50}=13.5 \\
\text { and } 13.7 \mu \mathrm{M}\end{array}$ & [59] \\
\hline $\begin{array}{l}\text { Penicillum } \\
\text { granulatum } \\
\text { MCCC } \\
\text { 3A00475 }\end{array}$ & Spirograterpene A & Antiallergic activity & $\begin{array}{l}2284 \mathrm{~m} \\
\text { Prydz Bay of } \\
\text { Antarctica }\end{array}$ & $20 \mu \mathrm{g} / \mathrm{mL}$ & {$[60]$} \\
\hline $\begin{array}{l}\text { Penicillium } \\
\text { chrysogenum } \\
\text { SCSIO } 07007\end{array}$ & $\begin{array}{l}\text { Chrysopyrones A } \\
\text { and B }\end{array}$ & $\begin{array}{c}\text { Inhibited protein-tyrosine } \\
\text { phosphatase-1B (PTP1B) involved } \\
\text { in diabetes mellitus }\end{array}$ & $\begin{array}{l}1000 \mathrm{~m} \\
\text { Western Atlantic }\end{array}$ & $\begin{array}{l}\mathrm{IC}_{50}=9.32 \text { and } \\
27.8 \mu \mathrm{g} / \mathrm{mL} \\
\text { respectively }\end{array}$ & {$[61]$} \\
\hline $\begin{array}{l}\text { Engyodontium } \\
\text { album } \\
\text { DFFSCS021 }\end{array}$ & $\begin{array}{l}\text { Engyodontiumone } \mathrm{H} \\
\text { (Compound 8) and a } \\
\text { polyketide } \\
\text { (Compound16) } \\
\text { Compounds } 8 \text { and } \\
\text { the polyketides } \\
\text { compounds } \\
15 \text { and } 16\end{array}$ & $\begin{array}{l}\text { Cytotoxic activity against human } \\
\text { histiocitic lumphoma U937 } \\
\text { Antibacterial activity against } \\
\text { Escherichia coli and Bacillus subtilis }\end{array}$ & $\begin{array}{l}3739 \mathrm{~m} \\
\text { South China Sea }\end{array}$ & $\begin{array}{c}\mathrm{IC}_{50}=4.9 \text { and } 8.8 \mu \mathrm{M} \\
\text { respectively } \\
\mathrm{MIC} \leq 64 \mu \mathrm{g} / \mathrm{mL}\end{array}$ & {$[62]$} \\
\hline $\begin{array}{l}\text { Acrostalagmus } \\
\text { luteoalbus } \\
\text { SCSIO F } 457\end{array}$ & Luteoalbusins A, B & $\begin{array}{l}\text { Cytotoxic activity against SF-268, } \\
\text { MCF-7, NCI-H460 and HepG2 }\end{array}$ & $\begin{array}{l}2801 \mathrm{~m} \\
\text { South China Sea }\end{array}$ & $\begin{array}{c}\mathrm{IC}_{50} \text { from } \\
0.23 \text { to } 1.31 \mu \mathrm{M}\end{array}$ & {$[63]$} \\
\hline $\begin{array}{l}\text { Aspergillus } \\
\text { versicolor }\end{array}$ & $\begin{array}{l}\text { Oxisterigmatocystin } \\
\qquad \mathrm{A}-\mathrm{C}\end{array}$ & $\begin{array}{l}\text { Cytotoxic activity against A549 } \\
\text { and HL-60 }\end{array}$ & $\begin{array}{c}800 \mathrm{~m} \\
\text { Pacific Ocean }\end{array}$ & $\begin{array}{l}\text { Moderate low } \\
\text { micromolar } \\
\text { cytotoxicity }\end{array}$ & {$[64]$} \\
\hline $\begin{array}{l}\text { Penicillium sp. } \\
\text { MCCC } \\
\text { 3A00005 }\end{array}$ & Brevione I & $\begin{array}{l}\text { Cytotoxicity against MCF-7 cells } \\
\text { and A549 cells }\end{array}$ & $\begin{array}{l}5115 \mathrm{~m} \\
\text { East Pacific }\end{array}$ & $\begin{array}{c}\mathrm{IC}_{50}=7.44 \mu \mathrm{M} \text { and } \\
32.5 \mu \mathrm{M}, \text { respectively }\end{array}$ & {$[65]$} \\
\hline $\begin{array}{l}\text { Penicillium sp. } \\
\text { MCCC } \\
\text { 3A00005 }\end{array}$ & Brevione A & Cytotoxicity against MCF-7 cells & $\begin{array}{l}\quad 5115 \mathrm{~m} \\
\text { East Pacific }\end{array}$ & $\mathrm{IC}_{50}=28.4 \mu \mathrm{M}$ & [65] \\
\hline $\begin{array}{l}\text { Penicillium sp. } \\
\text { F00120 }\end{array}$ & Penicilliumin A & $\begin{array}{l}\text { Moderately inhibited the in vitro } \\
\text { proliferation of mouse melanoma } \\
\text { (B16), human melanoma (A375), } \\
\text { and human cervical carcinoma } \\
\text { (Hela) cell lines }\end{array}$ & $\begin{array}{l}1300 \mathrm{~m} \\
\text { South China Sea }\end{array}$ & $\begin{array}{c}\mathrm{GI}_{50}=27.37,22.88, \text { and } \\
44.05 \mu \mathrm{g} / \mathrm{mL}, \\
\text { respectively }\end{array}$ & {$[66]$} \\
\hline $\begin{array}{l}\text { Penicillium sp. } \\
\text { F23-2 }\end{array}$ & Sorbicillamines A-E & $\begin{array}{l}\text { Cytotoxic activity on HeLa, } \\
\text { BEL-7402, HEK-293, HCT-116, } \\
\text { and P388 cell line }\end{array}$ & $\begin{array}{l}5080 \mathrm{~m} \\
\text { Huiquan bay, } \\
\text { yellow Sea }\end{array}$ & $\mathrm{IC}_{50}>10 \mu \mathrm{M}$ & {$[67]$} \\
\hline
\end{tabular}

Abbreviations: $\mathrm{EC}_{50}$ for Half-maximal effective concentration; $\mathrm{MIC}$ for minimum inhibitory concentration; $\mathrm{IC}_{50}$ for the concentration $(\mu \mathrm{g} / \mathrm{mL})$ inducing $50 \%$ loss of cell viability; $\mathrm{GI}_{50}$ for $50 \%$ of maximal inhibition of cell proliferation; MCF7 for breast cancer cell line, SF-268 for human glioblastoma cell line, LPS for lipopolysaccharide; NO for nitric oxide; RAW 264.7 for macrophage cell line; RBL-2H3 for basophilic leukemia cell line; A549 for lung cancer cells; HeLa for cervical cancer cells; BEL-7402 for human papillomavirus-related endocervical adenocarcinoma; HEK-293 for human embryonic kidney; HCT-116 for human colon cancer cells; P388 for murine leukemia cells lines; "-" means that there is a lack of corresponding information.

Three new phenolicbisabolane sesquiterpenes-peniciaculins A and B (1 and 2) and (7S)-(-)-10-hydroxysydonic acid (3) - as well as a new nor-bisabolane derivative 1-hydroxy- 
boivinianin A (4), and six known bisabolane sesquiterpenes (5-10), were isolated and identified from the culture extract of Penicillium aculeatum SD-321 found in the South China Sea at a depth of $2038 \mathrm{~m}$ [48]. Compounds 1-10 were evaluated for antimicrobial activity against two pathogenic bacteria (Escherichia coli and Staphyloccocus aureus) and eight aquatic pathogens (Aeromonas hydrophilia, Edwardsiella tarda, Micrococcus luteus, Pseudomonas aeruginosa, Vibrio alginolyticus, Vibrio anguillarum, Vibrio harveyi, and Vibrio parahemolyticus) as well as three plant-pathogenic fungi (Alternaria brassicae, Colletotrichum gloeos-prioides and Gaeumannomyces graminis). Compound 1 showed inhibitory activity against $M$. luteus and $V$. alginolyticus with MIC values of 1.0 and $2.0 \mu \mathrm{g} / \mathrm{mL}$, while compounds 2 and 4 exhibited selective antibacterial activity against $E$. tarda and $V$. harveyi, with MIC values of 8.0 and $4.0 \mu \mathrm{g} / \mathrm{mL}$ respectively. Compound 6 showed significant inhibitory activity against S. aureus and V. parahemolyticus with MIC values of $0.5 \mu \mathrm{g} / \mathrm{mL}$. Regarding antifungal activity, compound 1 showed inhibitory activity against $A$. brassicae with a MIC of $0.5 \mu \mathrm{g}$ against $S$. aureus and V. parahemolyticus with MIC values of $0.5 \mu \mathrm{g} / \mathrm{mL}$ which is more potent than that of the positive control amphotericin B (MIC $64 \mu \mathrm{g} / \mathrm{mL}$ ). Compounds 1-10 were also evaluated for lethal activity against brine shrimp (Artemia salina), but none of them displayed significant activity $\left(\mathrm{LD}_{50}>10 \mu \mathrm{g} / \mathrm{mL}\right)$ [48].

Guo et al. [49] collected Penicillium sp. F23-2 in Jiaozhou Bay at $5080 \mathrm{~m}$ depth, and isolated Penycyclones A-E that showed antimicrobial activity against Gram-positive bacterium Staphylococcus aureus with a MIC value from 0.3 to $1 \mu \mathrm{g} / \mathrm{mL}$ [49]. Spiromastix sp. MCCC3A00308 was isolated from sediments collected from the South Atlantic Ocean at a depth of $2869 \mathrm{~m}$. A new class of phenolic lactones, including spiromastilactones A-M, was isolated from this fungus. These compounds reveal an antiviral activity against influenza virus replication in vitro [50]. In 2017 Xiao Ling and co-workers isolated from the fungus Simplicillium obclavatum EIODSF 020 (sampling depth at $4571 \mathrm{~m}$ ) different cyclic peptides; in particular, some of these showed antifungal and antiviral activity including simplicilliumtide J, verlamelins A and B. Antifungal activity was detected against Aspergillus versicolor and Curvularia australiensis with a minimum inhibitory concentration of $50 \mu \mathrm{g} / \mathrm{mL}$ and an antiviral activity towards HSV-1 with an $\mathrm{IC}_{50} 14.0,16.7$ and $15.6 \mu \mathrm{M} / \mathrm{mL}$, respectively [51]. In addition to antibacterial, antifungal and antiviral, other bioactivities were found for fungal derived compounds from the deep sea. Fifteen new eremophilane-type sesquiterpenoids, acremeremophilanes $\mathrm{A}-\mathrm{O}$, were isolated from the fungus Acremonium sp. from deep-sea sediments (sampling depth of $2869 \mathrm{~m}$ ) in the South Atlantic Ocean [52]. Acremeremophilane B $\left(\mathrm{EC}_{50} 8 \mu \mathrm{M}\right)$ and $\mathrm{E}\left(\mathrm{EC}_{50} 15 \mu \mathrm{M}\right)$ showed comparatively potent inhibitory effects towards LPS-induced NO production in RAW 264.7 cells with possible anti-inflammatory activity. Another fungus was collected from sediments at the extreme depth of $5610 \mathrm{~m}$ in the South Atlantic Ocean, the fungus Eutypella sp. MCCC3A00281. Using chromatographic application of the extended metabolites led to the isolation of a total of 30 eremophilane-type sesquiterpenoids, of which 26 were identified as new compounds, namely eutyperemophilane A-Z [53]. Eutyperemophilane I and J showed comparatively potent inhibitory effects towards nitric oxide (NO) production as induced by lipopolysaccharide (LPS) in Raw 264.7 macrophage cells ( $\mathrm{IC}_{50}$ of 8.6 and $13 \mu \mathrm{M}$, respectively), suggesting they could be promising anti-inflammatory agents [53]. Three dimeric nitrophenyl trans-epoxyamides, chrysamides A-C, were obtained from the deep-sea fungus Penicillium chrysogenum SCSIO411001 collected in the Indian Ocean at a depth of $3386 \mathrm{~m}$. Chrysamide $\mathrm{C}$ exhibited inhibitory effects on the production of the pro-inflammatory cytokine Interleukin-17. The inhibitory rate of the production of IL-17 was $40.06 \%$ at $1.0 \mu \mathrm{M}$, while compounds B and C did not show any inhibitory effects at $50 \mu \mathrm{M}[54]$.

Recently, Lu et al. [55] also isolated novel compounds having anti-inflammatory activity from deep-sea fungi (sampling depth at $2130 \mathrm{~m}$ ), a pair of 2-benzoyl tetrahydrofuran enantiomers, named (-)-1S-myrothecol, (+)-1R-myrothecol, methoxy-myrothecol, and an azaphilone derivative, myrothin, from the culture filtrates of the deep sea-derived fungus, Myrothecium sp. BZO-L062 [55]. The isolated compounds showed cellular anti- 
inflammatory activity inhibiting nitric oxide (NO) formation in LPS-treated macrophagelike cells. Furthermore, the antioxidant activity was measured by oxygen radical absorbance capacity (ORAC) and both compounds showed antioxidant activity in the ORAC assay with $\mathrm{EC}_{50}$ of 1.20 and $1.41 \mu \mathrm{g} / \mathrm{mL}$, respectively. Very recently, Wang et al. [56] isolated two benzodiazepine derivatives - cyclopenol and cyclopenin-from the extract of the fungal strain Aspergillus sp. SCSIOW2, collected from deep marine sediments in the South China Sea at a depth of $2439 \mathrm{~m}$. The authors demonstrated that cyclopenol and cyclopenin inhibited the lypopolysaccharide-induced (LPS) formation of nitric oxide and the secretion of interleukin-6 (IL-6) in Raw 264.7 cells. IL-6 is a soluble mediator with a pleiotropic effect on inflammation, immune response, and hematopoiesis. In particular, cyclopenol and cyclopenin were found to inhibit the upstream signal of nuclear factor-kappa B (NF- $\mathrm{kB}$ ) activation at 50 and $100 \mu \mathrm{M}$, respectively. Furthermore, these compounds also inhibited the expression of interleukin-1 $\beta$, IL-6 and iNOS in mouse microglia cells, and macrophages in the brain. Cyclopenol was reported to inhibit human bladder cancer cell line BIU-87 (IC 50 of $8.34 \mu \mathrm{M}$ ) [57] and was also shown to inhibit protein-tyrosine phosphatase 1B (PTP1B) in a dose-dependent manner with an $\mathrm{IC}_{50}$ value of $30 \mu \mathrm{M}$ [58]. PTP1B catalyzes dephosphorylation of phosphotyrosine residues in the insulin receptor, inhibiting post-receptor signaling in insulin responsive tissue, and is associated with the development of type-2 diabetes [68]. Fructigenine A, echinulin, flavoglaucin and viridicatol from the deep fungi Penicillium spp. and Eurotium sp were also found able to inhibit PTP1B [58].

The fungus Graphostroma sp. MCC3A00421 was isolated from deep-sea hydrothermal sulfide deposits from the Atlantic Ocean at a depth of $2721 \mathrm{~m}$ [59]. The isolated compounds from Graphostroma sp. were tested for cellular anti-food allergic bioactivity in antigen and IgE-treated RBL-2H3 cells (basophilic leukemia cell lines). Reticulol, a known polyketide, effectively decreased the rates of degranulation and histamine release, with $\mathrm{IC}_{50}$ values of 13.5 and $13.7 \mu \mathrm{M}$. Penicillum granulatum MCCC3A00475 the extract derived from this deep (sampling depth at $2284 \mathrm{~m}$ ) fungi showed promising antiallergic activity. This was measured for the efficiency of the RBL-2H3 cell degranulation inhibition rate using an IgE-mediated mast cell allergic reaction. Spirograterpene A showed an antiallergic effect on immunoglobulin E (IgE)-mediated rat mast RBL-2H3 cells with 18\% inhibition compared to $35 \%$ inhibition for the positive control, loratadine, at the same concentration of $20 \mu \mathrm{g} / \mathrm{mL}$. Conidiogenone I and conidiogenone $\mathrm{C}$ exhibited weak effects with inhibition of $4 \%$ and $10 \%$, respectively, at $20 \mu \mathrm{g} / \mathrm{mL}$ [60]. The fungus Penicillium chrysogenum SCSIO 07007 was isolated from deep-sea hydrothermal vents from the Western Atlantic Ocean at a depth of $\sim 1000 \mathrm{~m}$. Chrysopyrones A and B obtained from Penicillium chrysogenum inhibited proteintyrosine phosphatase-1B (PTP1B) involved in diabetes mellitus [61] with $\mathrm{IC}_{50}$ values of 9.32 and $27.8 \mu \mathrm{g} / \mathrm{mL}$, respectively. Finally, Yao et al. isolated from the deep-sea fungus Engyodontium album DFFSCS021, eight new chromones, engyodontiumones A-H (1-8), and eight known polyketides (9-16). These polyketide compounds show a significant selective cytotoxicity against the human histiocytic lymphoma U937 cell line with $\mathrm{IC}_{50}$ of 4.9-8.8 $\mu \mathrm{M}$. In addition, compounds 8,12, and 13 exhibit mild antibacterial activity against Escherichia coli and Bacillus subtilis [62]. Luteoalbusins A and B were isolated from the fungus Acrostalagmus luteoalbus SCSIO F457 originating from a deep-sea sediment sample collected at a depth of $2801 \mathrm{~m}$ in the South China Sea [63]. The novel compounds displayed strong cytotoxic activities against four cancer cell lines (SF-268, MCF-7, NCI-H460 and HepG2) with $\mathrm{IC}_{50}$ values in the range of $0.23-1.31 \mu \mathrm{M}$ and were significantly more potent that the control cisplatin. The deep-sea fungus Aspergillus versicolor obtained from $800 \mathrm{~m}$ depth in the Pacific Ocean has furnished three new sterigmatocystin derivatives: oxisterigmatocystin A-C. These compounds were evaluated for cytotoxicity towards A549 and HL-60 cell lines, and are currently the only known compounds of this class to exhibit moderately low micromolar cytotoxicity [64]. In 2009, Li's group reported the isolation and characterization of three new bioactive breviane spiroditerpenoids, breviones $\mathrm{F}-\mathrm{H}$, from the deep-sea sediment derived fungus Penicillium sp. (MCCC 3A00005) collected at a depth of $5115 \mathrm{~m}$ in the east Pacific [69]. Brevione I exhibited significant cytotoxicity 
against MCF-7 cells [65]. The fungus Penicillium sp. (F00120), recovered from deep-sea sediments obtained at a depth of $1300 \mathrm{~m}$ from the northern South China Sea, yielded the new sesquiterpene quinone, penicillium $\mathrm{A}$, along with known ergosterol and ergosterol peroxide. Penicillium A moderately inhibited the in vitro proliferation of mouse melanoma (B16), human melanoma (A375) and human cervical carcinoma (Hela) cell lines [66]. Sorbicillamines A-E were isolated from the deep-sea fungus Penicillum sp. F23-2 and evaluated for their cytotoxicity against HeLa (human cervical cancer cell line), BEL-7402 (human hepatocellular carcinoma cell line), HEK-293 (human embryonic kidney cell line), HCT116 (human colon cancer cell line) and P388 (leukemia cell line) cell lines. $\mathrm{IC}_{50}$ values were > $10 \mu \mathrm{M}$, respectively [67].

Table 3. Bioactive compounds from deep-sea Cnidaria.

\begin{tabular}{ccccc}
\hline Marine Organism & Activity/Experimental Model & Depth/Site & Concentrations & Ref. \\
\hline Aegina citrea & Citotoxicity test against Leukemia L1210 cells & $\begin{array}{l}200-1000 \mathrm{~m} \\
\text { Sagami Bay }\end{array}$ & $\mathrm{IC}_{50}=100 \mathrm{mg} / \mathrm{mL}$ & {$[70]$} \\
\hline Crossota rufobrunea & Hemolytic activity test of suspension of sheep red & $\begin{array}{l}200-1000 \mathrm{~m} \\
\text { blood cells }\end{array}$ & $\mathrm{ED}_{50}=100 \mathrm{mg} / \mathrm{mL}$ & {$[70]$} \\
\hline Atolla wyvillei & Crustacean letality test against shrimp Palaemon paucidens & $\begin{array}{l}200-1000 \mathrm{~m} \\
\text { Sagami Bay }\end{array}$ & $\mathrm{LD} 50=2 \mathrm{mg} / \mathrm{g}$ & {$[70]$} \\
\hline
\end{tabular}

Abbreviations: $\mathrm{IC}_{50}$ for the concentration $(\mu \mathrm{g} / \mathrm{mL})$ inducing $50 \%$ loss of cell viability; ED 50 for effective dose for $50 \%$ hemolysis of a $0.8 \%$ suspension of sheep red blood cells; LD 50 for lethal activity; HSV1 for herpes simplex 1.

\subsection{Cnidaria}

In Sagami Bay, between 2004 and 2009, Kawabata et al. [70] collected twelve deepsea jellyfishes from the mesopelagic zone (depth of 200-1000 m) in order to find useful polyketides, such as molecular probes for biochemical studies and drug applications. In particular, Kawabata demonstrated that three jellyfishes from the deep-sea had biological activity (Table 3). Aegina citrea showed cytotoxicity against leukemia cells L-1210 with an $\mathrm{IC}_{50}$ value of $100 \mathrm{mg} / \mathrm{mL}$, Crossota rufobrunea had hemolytic activity with an $\mathrm{ED}_{50}$ (effective dose for $50 \%$ hemolysis of a $0.8 \%$ suspension of sheep red blood cells) of $100 \mathrm{mg} / \mathrm{mL}$ and finally Atolla wyvillei was used for lethality tests against shrimp Palaemon paucidens with $\mathrm{LD}_{50} 2 \mathrm{mg} / \mathrm{g}$ [70].

\subsection{Porifera}

Marine sponges are the largest source of new marine natural products [71] and have provided a rich array of biologically important compounds [1]. Deep-water species of marine sponges have already provided important anticancer leads such as halicondrin and discodermolide [72] and are a rich new source of biologically and structurally interesting molecules. Four species of Porifera from the deep sea have shown biological activity as reported in Table 4 . 
Table 4. Bioactive compounds from deep-sea Porifera.

\begin{tabular}{|c|c|c|c|c|c|}
\hline $\begin{array}{l}\text { Marine } \\
\text { Organism }\end{array}$ & Compound & $\begin{array}{l}\text { Activity/Experimental } \\
\text { Model }\end{array}$ & Depth/Site & Concentration & Ref. \\
\hline Petrosia sp. & $(-)$-Duryne and (-)-Durynes B-F & $\begin{array}{l}\text { Cytotoxic against } \\
\text { HeLa cells }\end{array}$ & $\begin{array}{l}415 \mathrm{~m} \\
\text { Japan }\end{array}$ & $\begin{array}{c}\mathrm{IC}_{50} \text { from } 0.08 \text { to } \\
0.5 \mu \mathrm{M}\end{array}$ & [73] \\
\hline Xestospongia sp. & Alisiaquinones $\mathrm{A}-\mathrm{C}$ & $\begin{array}{c}\text { Antimalarial } \\
\text { against Plasmodium } \\
\text { falciparum }\end{array}$ & $\begin{array}{l}250 / 400 \mathrm{~m} \\
\text { Australia }\end{array}$ & Submicromolar & [74] \\
\hline Leiodermatium sp. & Leiodermatolide & Antimitotic & $\begin{array}{l}401 \mathrm{~m} \\
\text { USA }\end{array}$ & $\mathrm{IC}_{50}<10 \mathrm{nM}$ & [75] \\
\hline Latrunculia sp. & $\begin{array}{l}\text { Discorhabdin A and } \\
\text { Dihydrodiscorhabdin C }\end{array}$ & Anti-HCV & $\begin{array}{l}230 \mathrm{~m} \\
\text { Alaska }\end{array}$ & $\mathrm{EC}_{90}<10 \mu \mathrm{M}$ & [76] \\
\hline
\end{tabular}

Abbreviations: $\mathrm{IC}_{50}$ for the concentration $(\mu \mathrm{g} / \mathrm{mL})$ inducing $50 \%$ loss of cell viability; EC 90 for the $90 \%$ effective concentration in the $\mathrm{HCV}$ replicon assay; less than $10 \mu \mathrm{M}$ is considered active. HCV for hepatitis C virus. HeLa cervical cancer cell lines.

Hitora et al. isolated from Petrosia sp. six linear acetylenes (-)-duryne and (-)durynes B-F. These compounds showed cytotoxic activity against HeLa cells with $\mathrm{IC}_{50}$ values between 0.08 and $0.50 \mu \mathrm{M}$ [73]. Desoubzdanne et al. [74] isolated from a deepsponge Xestospongia sp. the molecules alisiaquinones $\mathrm{A}-\mathrm{D}$, and found that compound $\mathrm{C}$ displayed a submicromolar activity on Plasmodium falciparum. From Leiodermatium sp. a promising new lead for anticancer drug discovery Leiodermatolide was found to exhibit potent and selective antimitotic activity $\mathrm{IC}_{50}<10 \mathrm{nM}$ against a range of human cancer cell lines by inducing G2/M cell cycle arrest [75]. Minkyun Na et al., [76] isolated from a new deep-water Alaskan sponge species of the genus Latrunculia two compounds, discorhabdin $\mathrm{A}$ and dihydrodiscorhabdin $\mathrm{C}$, that showed anti-hepatitis $\mathrm{C}$ virus (HCV) activity with an $\mathrm{EC}_{90}<10 \mu \mathrm{M}$ (Table 4).

\subsection{Mesopelagic Species}

Lauritano et al. [77] studied the potential antimicrobial (Gram-negative bacteria Escherichia coli and Klebsiella pneumoniae, the Gram-positive bacteria methicillin resistant/sensitive Staphylococcus aureus, and Mycobacterium tubercolosis) and anticancer activity (A549-lung cell line, A2058-melanoma cell line, HepG2 epatocarcinoma cell line, MCF-7-breast cell line and MiaPaca-2-pancreas cell line) of seven extracts of mesopelagic species (Meganyctiphanes norvegica; Hygophum benoiti, Myctophum punctatum, Lampanyctus crocodilus, Argyropelecus hemygimnus, Chauliodus sloani and Stomias boa boa). They found the most significant activity in the fish Myctophum punctatum (Family Mictophidae) and the krill Meganyctiphanes norvegica (Family Euphausiidae) (Table 5). M. punctatum showed anticancer activity against A549 and MCF-7 cancer cells, while M. norvegica was more active against HepG2 cancer cell lines. For M. punctatum $\mathrm{IC}_{50}$ for A549 was 13.77-23.26, while the $\mathrm{IC}_{50}$ for MCF7 was 25.34-29.62 $\mu \mathrm{g} / \mathrm{mL}$. For M. norvegica $\mathrm{IC}_{50}$ for HepG2 cells was between 3.81 and $7.51 \mu \mathrm{g} / \mathrm{mL}$. M. punctatum and M. norvegica extracts were able to inhibit the growth of methicillin-resistant Staphylococcus aureus (MRSA) and methicillin-sensitive Staphylococcus aureus (MSSA). M. punctatum extract was able to inhibit 100\% MRSA viability at extract concentrations between 40 and $320 \mu \mathrm{g} / \mathrm{mL}$. M. norvegica was active against MRSA from $80-320 \mu \mathrm{g} / \mathrm{mL}$ [77]. 
Table 5. Bioactive compounds from deep-sea mesopelagic organisms.

\begin{tabular}{|c|c|c|c|c|}
\hline Marine Organism & Activity/Experimental Model & Depth/Site & Concentrations & Ref. \\
\hline \multirow[t]{2}{*}{ Myctophum punctatum } & $\begin{array}{l}\text { Antiproliferative activity } \\
\text { against A549 and MCF7 }\end{array}$ & $\begin{array}{c}200-1000 \mathrm{~m} \\
\text { Straits of Messina } \\
\text { (central Mediterranean Sea) }\end{array}$ & $\begin{array}{c}\mathrm{IC}_{50}=13.77-23.26 \text { and } \\
25.34-29.62 \mu \mathrm{g} / \mathrm{mL} \text {, respectively }\end{array}$ & [77] \\
\hline & $\begin{array}{c}\text { Antibacterial activity against } \\
\text { MRSA }\end{array}$ & & $\mathrm{IC}_{50}=40$ and $320 \mu \mathrm{g} / \mathrm{mL}$ & \\
\hline $\begin{array}{l}\text { Meganyctiphanes } \\
\text { norvegica }\end{array}$ & $\begin{array}{l}\text { Antiproliferative activity } \\
\text { against HepG2 }\end{array}$ & $\begin{array}{c}200-1000 \mathrm{~m} \\
\text { Straits of Messina } \\
\text { (central Mediterranean Sea) }\end{array}$ & $\mathrm{IC}_{50}=3.81$ and $7.51 \mu \mathrm{g} / \mathrm{mL}$ & [77] \\
\hline & $\begin{array}{l}\text { Antibacterial activity } \\
\text { against MRSA }\end{array}$ & & $\mathrm{IC}_{50}=80-320 \mu \mathrm{g} / \mathrm{mL}$ & \\
\hline
\end{tabular}

Abbreviations: $\mathrm{IC}_{50}$ for the concentration $(\mu \mathrm{g} / \mathrm{mL})$ inducing $50 \%$ loss of cell viability; MCF7 for breast cancer cell line; A549 for lung cancer cells; MRSA for methicillin resistant Staphylococcus aureus; MSSA for methicillin sensitive Staphylococcus aureus.

\section{Other Deep-Sea Organisms}

In addition to the above reported organisms, there are other species living in deep environments with biological activities (Table 6). Appleton et al. [78] isolated Rossinones A and B from the colonial sea squirt Aplidium sp. (sampling depth at $200 \mathrm{~m}$ ) that inhibited superoxide production when either $N$-formyl-methionyl-leucyl-phenylananine (fMLP) ( $\mathrm{IC}_{50} 1.9$ and $2.5 \mu \mathrm{M}$, respectively) or phorbol myristate acetate (PMA) (IC $\mathrm{C}_{50} 0.8$ and $0.7 \mu \mathrm{M}$, respectively) were used to activate a respiratory burst. These two compounds also showed selective antiviral activity against DNA virus HSV-1 at $2 \mu \mathrm{g} /$ disk.

Table 6. Synopsis of new natural products isolated from deep-sea organisms.

\begin{tabular}{|c|c|c|c|c|c|c|}
\hline Phylum & $\begin{array}{c}\text { Marine } \\
\text { Organism }\end{array}$ & Compound & $\begin{array}{c}\text { Activity/Experimental } \\
\text { Model }\end{array}$ & Depth/Site & Concentration & Ref. \\
\hline Chordata & Aplidium sp. & $\begin{array}{l}\text { Rossinones A } \\
\text { and B }\end{array}$ & $\begin{array}{c}\text { Antileukemic, } \\
\text { anti-inflammatory } \\
\text { and antiviral against HSV-1 }\end{array}$ & $\begin{array}{c}200 \mathrm{~m} \\
\text { Antarctica }\end{array}$ & $\begin{array}{c}\mathrm{IC}_{50}=1.9 \text { and } \\
2.5 \mu \mathrm{M} \\
2 \mu \mathrm{g} / \text { disk }\end{array}$ & [78] \\
\hline Echinodermata & Holopus rangii & $\begin{array}{l}\text { Gymnochromes E } \\
\text { and F }\end{array}$ & $\begin{array}{c}\text { Antiproliferative against } \\
\text { NCI/ADRRes }\end{array}$ & $\begin{array}{c}358 \mathrm{~m} \\
\text { Caribbean }\end{array}$ & $\mathrm{IC}_{50}=3.5 \mu \mathrm{M}$ & [79] \\
\hline Mollusca & $\begin{array}{l}\text { Bathymodiolus } \\
\text { thermophilus }\end{array}$ & $\begin{array}{l}\text { Bathymodiolamides } \\
\qquad \text { A and B }\end{array}$ & $\begin{array}{l}\text { Anticancer against HeLa and } \\
\text { MCF-7 cell lines }\end{array}$ & $\begin{array}{l}1733 \mathrm{~m} \\
\text { Mid-Atlantic } \\
\text { ridge }\end{array}$ & $\begin{array}{c}\mathrm{IC}_{50}=0.4 \mu \mathrm{M} \text { and } \\
0.5 \mu \mathrm{M} ; \\
\mathrm{IC}_{50}=0.1 \mu \mathrm{M} \text { and } \\
0.2 \mu \mathrm{M}\end{array}$ & [80] \\
\hline
\end{tabular}

Abbreviations: $\mathrm{IC}_{50}$ for the concentration $(\mu \mathrm{g} / \mathrm{mL})$ inducing $50 \%$ loss of cell viability. NCI/ADRRes multidrug-resistant ovarian cancer cell line; HSV-1 for herpes simplex-1. HeLa for cervical cancer cells, MCF7 for breast cancer cell.

From the echinoderm species Holopus rangii (sampling depth at $358 \mathrm{~m}$ ), Wangun et al. [79] isolated gymnochromes E and F, and 7-bromoemodic acid. Gymnochrome E inhibited the proliferation of NCI/ADRRes (multidrug-resistant ovarian cancer cell line) with an $\mathrm{IC}_{50}$ value of $3.5 \mu \mathrm{M}$. Furthermore, gymnochrome E exhibited minimum inhibitor concentrations (MICs) of $25 \mu \mathrm{g} \mathrm{mL}^{-1}$ against both Staphylococcus aureus and methicillin-resistant S. aureus (MRSA), while gymnochrome F exhibited MICs of $12.5 \mu \mathrm{g} \mathrm{mL}{ }^{-1}$ against $S$. aureus and MRSA [79]. The deep-sea mollusc Bathymodiolus thermophilus, collected from an active hydrothermal vent in the north of Lucky Strike in the Mid-Atlantic Ridge, at a depth of 1733, has furnished the first reported molluscan deep-sea small metabolites, bathymodiolamides $\mathrm{A}$ and $\mathrm{B}$, which exhibited apoptosis induction and potential anticancer activity. The compounds inhibit the growth of two cancer cell lines, cervical cancer HeLa cells, with $\mathrm{IC}_{50}$ $0.4 \mu \mathrm{M}$ and $0.5 \mu \mathrm{M}$, respectively, and breast cancer MCF-7 cells with $\mathrm{IC}_{50}$ values of $0.1 \mu \mathrm{M}$ and $0.2 \mu \mathrm{M}$, respectively [80]. 


\section{Conclusions}

Since the first report of biologically active MNP spongothymidine in 1950, 30,000 MNPs have been identified, but only $0.05 \%$ of these have reached the market and are currently used for the treatment of human pathologies. In the last 70 years, there has been an increasing interest in MNPs as demonstrated by the increased number of publications (Figure 1). Studies have highlighted that $\sim 70 \%$ of MNP have structural scaffolds that are unique for the marine environment. Due to sampling and culturing difficulties, the deep ocean has been poorly studied compared to other marine environments. However, recent molecular tools, in situ experiments, sensor-tagged species and video recordings are giving a boost to the available limited biological knowledge of the deep-sea. Studies have provided evidence that thousands of species live in the deep sea, mainly microorganisms, suggesting that the deep sea may be a potential rich source of structurally diverse, biologically active compounds waiting to be explored. In the deep-sea environment there are a high number of single rare species, with more than half being new to science, with some taxa possessing $>95 \%$ of undescribed species. The aims of this review were (1) to provide an overview of the bioactive molecules isolated from deep extreme environments already on the market or under investigation for possible industrial applications and (2) to encourage further research to study the potential of deep-sea organisms.

In the last 10 years, several projects have been funded to implement an eco-sustainable approach to drug discovery, favoring species cultivation, advanced dereplication, metabolite production stimulation in the laboratory and in silico analyses to avoid disruptive collection practices in the deep sea. These efforts will also support preservation strategies of deep-sea ecosystems and mitigation of exploitation impacts.

Other approaches are being implemented to study the deep sea, such as genomics, transcriptomics, and metabolomics, combined with innovative chemical analyses, phenotypic screening as well as bioinformatic tools and genetic engineering methodologies. Increased interest in natural product drug discovery in the deep sea over the last decade can be accelerated via academic and biotechnology industry collaboration. A multidisciplinary approach may represent a successful method to identify and biological characterize new marine natural products for the next generation of new bioactive compounds that may be even more potent and selective for the treatment or prevention of human pathologies.

Author Contributions: Conceptualization, A.S., C.L. and A.I.; writing-original draft preparation, A.S. and C.L.; supervision, C.L. and A.I.; writing-review and editing, A.S., C.L. and A.I. All authors have read and agreed to the published version of the manuscript.

Funding: This study was supported by the project "Antitumor Drugs and Vaccines from the Sea (ADViSE)" (CUP B43D18000240007-SURF 17061BP000000011, PG/2018/0494374) funded by POR Campania FESR 2014-2020 “Technology Platform for Therapeutic Strategies against Cancer"-Action 1.1.2 and 1.2.2.

Institutional Review Board Statement: Not applicable.

Informed Consent Statement: Not applicable.

Data Availability Statement: Not applicable.

Acknowledgments: Authors thank Servier Medical Art (SMART) website (https:/ /smart.servier. $\mathrm{com} /$, accessed on 8 October 2021) by Servier for elements in Figures 2 and 3.

Conflicts of Interest: The authors declare no conflict of interest.

\section{References}

1. Skropeta, D.; Wei, L. Recent advances in deep-sea natural products. Nat. Prod. Rep. 2014, 31, 999-1025. [CrossRef]

2. Danovaro, R.; Fanelli, E.; Aguzzi, J.; Billett, D.; Carugati, L.; Corinaldesi, C.; Dell'Anno, A.; Gjerde, K.; Jamieson, A.J.; Kark, S.; et al. Ecological variables for developing a global deep-ocean monitoring and conservation strategy. Nat. Ecol. Evol. 2020, 4, 181-192. [CrossRef]

3. Danovaro, R.; Snelgrove, P.V.R.; Tyler, P. Challenging the paradigms of deep-sea ecology. Trends Ecol. Evol. 2014, 29, 465-475. [CrossRef] [PubMed] 
4. Metaxas, A.; Nunoura, T.; Baker, B.J.; Corinaldesi, C. New perspectives in benthic deep-sea microbial ecology Deep-Sea Microbial Ecology: An Exciting Challenge in Marine Ecology. Front. Mar. Sci. 2015, 2, 17. [CrossRef]

5. Danovaro, R.; Corinaldesi, C.; Dell'Anno, A.; Snelgrove, P.V.R. The deep-sea under global change. Curr. Biol. 2017, 27, R461-R465. [CrossRef]

6. Danovaro, R.; Carugati, L.; Berzano, M.; Cahill, A.E.; Carvalho, S.; Chenuil, A.; Corinaldesi, C.; Cristina, S.; David, R.; Dell'Anno, A.; et al. Implementing and innovating marine monitoring approaches for assessing marine environmental status. Front. Mar. Sci. 2016, 3, 1-25. [CrossRef]

7. Sorokina, M.; Steinbeck, C. Review on natural products databases: Where to find data in 2020. J. Cheminform. 2020, 12, 1-51. [CrossRef]

8. Newman, D.J.; Cragg, G.M. Natural Products as Sources of New Drugs over the Nearly Four Decades from 01/1981 to 09/2019. J. Nat. Prod. 2020, 83, 770-803. [CrossRef]

9. Lyu, C.; Chen, T.; Qiang, B.; Liu, N.; Wang, H.; Zhang, L.; Liu, Z. CMNPD: A comprehensive marine natural products database towards facilitating drug discovery from the ocean. Nucleic Acids Res. 2021, 49, D509-D515. [CrossRef]

10. Kong, D.X.; Jiang, Y.Y.; Zhang, H.Y. Marine natural products as sources of novel scaffolds: Achievement and concern. Drug Discov. Today 2010, 15, 884-886. [CrossRef]

11. Spainhour, C.B. Natural Products. In Drug Discovery Handbook; John Wiley Sons Inc.: Hoboken, NJ, USA, 2005 ; pp. 11-72. [CrossRef]

12. Skropeta, D. Deep-sea natural products. Nat. Prod. Rep. 2008, 25, 1131-1166. [CrossRef] [PubMed]

13. Glud, R.N.; Wenzhöfer, F.; Middelboe, M.; Oguri, K.; Turnewitsch, R.; Canfield, D.E.; Kitazato, H. High rates of microbial carbon turnover in sediments in the deepest oceanic trench on Earth. Nat. Geosci. 2013, 6, 284-288. [CrossRef]

14. Jiang, X.; Xu, X.; Huo, Y.; Wu, Y.; Zhu, X.; Zhang, X.; Wu, M. Identification and characterization of novel esterases from a deep-sea sediment metagenome. Arch. Microbiol. 2012, 194, 207-214. [CrossRef] [PubMed]

15. Kobayashi, T.; Uchimura, K.; Deguchi, S.; Horikoshi, K. Cloning and sequencing of inulinase and $\beta$-fructofuranosidase genes of a deep-sea Microbulbifer species and properties of recombinant enzymes. Appl. Environ. Microbiol. 2012, 78, 2493-2495. [CrossRef] [PubMed]

16. Murakami, C.; Ohmae, E.; Tate, S.I.; Gekko, K.; Nakasone, K.; Kato, C. Cloning and characterization of dihydrofolate reductases from deep-sea bacteria. J. Biochem. 2010, 147, 591-599. [CrossRef]

17. Cossins, A.R.; Macdonald, A.G. The adaptation of biological membranes to temperature and pressure: Fish from the deep and cold. J. Bioenerg. Biomembr. 1989, 21, 115-135. [CrossRef]

18. Jaspars, M.; De Pascale, D.; Andersen, J.H.; Reyes, F.; Crawford, A.D.; Ianora, A. The marine biodiscovery pipeline and ocean medicines of tomorrow. J. Mar. Biol. Assoc. U. K. 2016, 96, 151-158. [CrossRef]

19. Schöffski, P.; Dumez, H.; Wolter, P.; Stefan, C.; Wozniak, A.; Jimeno, J.; Van Oosterom, A.T. Clinical impact of trabectedin (ecteinascidin-743) in advanced/metastatic soft tissue sarcoma. Expert Opin. Pharmacother. 2008, 9, 1609-1618. [CrossRef]

20. National Center for Biotechnology Information. PubChem Compound Summary for CID 16135415, Ziconotide. Available online: https:/ / pubchem.ncbi.nlm.nih.gov/ compound/Ziconotide (accessed on 11 October 2021).

21. National Center for Biotechnology Information. PubChem Compound Summary for CID 108150, Trabectedin. Available online: https:/ / pubchem.ncbi.nlm.nih.gov/compound/Trabectedin (accessed on 11 October 2021).

22. Subramani, R.; Aalbersberg, W. Marine actinomycetes: An ongoing source of novel bioactive metabolites. Microbiol. Res. 2012, 167, 571-580. [CrossRef]

23. Mincer, T.J.; Fenical, W.; Jensen, P.R. Culture-dependent and culture-independent diversity within the obligate marine actinomycete genus Salinispora. Appl. Environ. Microbiol. 2005, 71, 7019-7028. [CrossRef]

24. Berdi, J. Bioactive Microbial metabolites. J. Antibiot. 2005, 58, 1-26. [CrossRef]

25. Nachtigall, J.; Schneider, K.; Bruntner, C.; Bull, A.T.; Goodfellow, M.; Zinecker, H.; Imhoff, J.F.; Nicholson, G.; Irran, E.; Süssmuth, R.D.; et al. Benzoxacystol, a benzoxazine-type enzyme inhibitor from the deep-sea strain Streptomyces sp. NTK 935. J. Antibiot. 2011, 64, 453-457. [CrossRef]

26. Braña, A.F.; Sarmiento-Vizcaíno, A.; Osset, M.; Pérez-Victoria, I.; Martín, J.; De Pedro, N.; De La Cruz, M.; Díaz, C.; Vicente, F.; Reyes, F.; et al. Lobophorin K, a new natural product with cytotoxic activity produced by Streptomyces sp. M-207 associated with the deep-sea coral Lophelia pertusa. Mar. Drugs 2017, 15, 144. [CrossRef]

27. Yan, X.; Zhou, Y.-X.; Tang, X.-X.; Liu, X.-X.; Yi, Z.-W.; Fang, M.-J.; Wu, Z.; Jiang, F.-Q.; Qiu, Y.-K. Macrolactins from Marine-Derived Bacillus subtilis B5 Bacteria as Inhibitors of Inducible Nitric Oxide and Cytokines Expression. Mar. Drugs 2016, 14, 195. [CrossRef]

28. Huang, H.; Yao, Y.; He, Z.; Yang, T.; Ma, J.; Tian, X.; Li, Y.; Huang, C.; Chen, X.; Li, W.; et al. Antimalarial $\beta$-carboline and indolactam alkaloids from Marinactinospora thermotolerans, a deep sea isolate. J. Nat. Prod. 2011, 74, 2122-2127. [CrossRef]

29. Zhou, X.; Huang, H.; Chen, Y.; Tan, J.; Song, Y.; Zou, J.; Tian, X.; Hua, Y.; Ju, J. Marthiapeptide A, an anti-infective and cytotoxic polythiazole cyclopeptide from a $60 \mathrm{~L}$ scale fermentation of the deep sea-derived Marinactinospora thermotolerans SCSIO 00652. J. Nat. Prod. 2012, 75, 2251-2255. [CrossRef] [PubMed]

30. Song, Y.; Li, Q.; Liu, X.; Chen, Y.; Zhang, Y.; Sun, A.; Zhang, W.; Zhang, J.; Ju, J. Cyclic hexapeptides from the deep South China sea-derived Streptomyces scopuliridis SCSIO ZJ46 active against pathogenic gram-positive bacteria. J. Nat. Prod. 2014, 77, 1937-1941. [CrossRef] 
31. Zhou, X.; Huang, H.; Li, J.; Song, Y.; Jiang, R.; Liu, J.; Zhang, S.; Hua, Y.; Ju, J. New anti-infective cycloheptadepsipeptide congeners and absolute stereochemistry from the deep sea-derived Streptomyces drozdowiczii SCSIO 10141. Tetrahedron 2014, 70, 7795-7801. [CrossRef]

32. Niu, S.; Li, S.; Chen, Y.; Tian, X.; Zhang, H.; Zhang, G.; Zhang, W.; Yang, X.; Zhang, S.; Ju, J.; et al. Lobophorins E and F, new spirotetronate antibiotics from a South China Sea-derived Streptomyces sp. SCSIO 01127. J. Antibiot. 2011, 64, 711-716. [CrossRef]

33. Pan, H.-Q.; Zhang, S.-Y.; Wang, N.; Li, Z.-L.; Hua, H.-M.; Hu, J.-C.; Wang, S.-J. New Spirotetronate Antibiotics, Lobophorins H and I, from a South China Sea-Derived Streptomyces sp. 12A35. Mar. Drugs 2013, 11, 3891-3901. [CrossRef]

34. Bister, B.; Bischoff, D.; Ströbele, M.; Riedlinger, J.; Reicke, A.; Wolter, F.; Bull, A.T.; Zähner, H.; Fiedler, H.-P.; Süssmuth, R.D. Abyssomicin C-A Polycyclic Antibiotic from a Marine Verrucosispora Strain as an Inhibitor of the p-Aminobenzoic Acid/Tetrahydrofolate Biosynthesis Pathway. Angew. Chem. Int. Ed. 2004, 43, 2574-2576. [CrossRef] [PubMed]

35. Song, Y.; Huang, H.; Chen, Y.; Ding, J.; Zhang, Y.; Sun, A.; Zhang, W.; Ju, J. Cytotoxic and antibacterial marfuraquinocins from the deep south china sea-derived Streptomyces niveus scsio 3406. J. Nat. Prod. 2013, 76, 2263-2268. [CrossRef] [PubMed]

36. Sarmiento-Vizcaíno, A.; Braña, A.F.; Pérez-Victoria, I.; Martín, J.; De Pedro, N.; De La Cruz, M.; Díaz, C.; Vicente, F.; Acuña, J.L.; Reyes, F.; et al. Paulomycin G, a new natural product with cytotoxic activity against tumor cell lines produced by deep-sea sediment derived Micromonospora matsumotoense M-412 from the Avilés Canyon in the Cantabrian Sea. Mar. Drugs 2017, 15, 271. [CrossRef]

37. Li, Y.; Xu, Y.; Liu, L.; Han, Z.; Lai, P.Y.; Guo, X.; Zhang, X.; Lin, W.; Qian, P.Y. Five new amicoumacins isolated from a marine-derived bacterium Bacillus subtilis. Mar. Drugs 2012, 10, 319-328. [CrossRef]

38. Abdel-Mageed, W.M.; Milne, B.F.; Wagner, M.; Schumacher, M.; Sandor, P.; Pathom-aree, W.; Goodfellow, M.; Bull, A.T.; Horikoshi, K.; Ebel, R.; et al. Dermacozines, a new phenazine family from deep-sea dermacocci isolated from a Mariana Trench sediment. Org. Biomol. Chem. 2010, 8, 2352-2362. [CrossRef]

39. Li, S.; Tian, X.; Niu, S.; Zhang, W.; Chen, Y.; Zhang, H.; Yang, X.; Zhang, W.; Li, W.; Zhang, S.; et al. Pseudonocardians A-C, new diazaanthraquinone derivatives from a deep-sea actinomycete Pseudonocardia sp. SCSIO 01299. Mar. Drugs 2011, 9, 1428-1439. [CrossRef]

40. Huang, H.; Yang, T.; Ren, X.; Liu, J.; Song, Y.; Sun, A.; Ma, J.; Wang, B.; Zhang, Y.; Huang, C.; et al. Cytotoxic angucycline class glycosides from the deep sea actinomycete Streptomyces lusitanus SCSIO LR32. J. Nat. Prod. 2012, 75, 202-208. [CrossRef] [PubMed]

41. Zhang, W.; Liu, Z.; Li, S.; Yang, T.; Zhang, Q.; Ma, L.; Tian, X.; Zhang, H.; Huang, C.; Zhang, S.; et al. Spiroindimicins A-D: New bisindole alkaloids from a deep-sea-derived actinomycete. Org. Lett. 2012, 14, 3364-3367. [CrossRef]

42. Hohmann, C.; Schneider, K.; Bruntner, C.; Irran, E.; Nicholson, G.; Bull, A.T.; Jones, A.L.; Brown, R.; Stach, J.E.; Goodfellow, M.; et al. Caboxamycin, a new antibiotic of the benzoxazole family produced by the deep-sea strain Streptomyces sp. NTK 937. J. Antibiot. 2009, 62, 99-104. [CrossRef]

43. Zhang, Q.; Li, S.; Chen, Y.; Tian, X.; Zhang, H.; Zhang, G.; Zhu, Y.; Zhang, S.; Zhang, W.; Zhang, C. New diketopiperazine derivatives from a deep-sea-derived Nocardiopsis alba SCSIO 03039. J. Antibiot. 2013, 66, 31-36. [CrossRef]

44. Moushumi Priya, A.; Jayachandran, S. Induction of apoptosis and cell cycle arrest by Bis (2-ethylhexyl) phthalate produced by marine Bacillus pumilus MB 40. Chem. Biol. Interact. 2012, 195, 133-143. [CrossRef] [PubMed]

45. Zhang, X.Y.; Zhang, Y.; Xu, X.Y.; Qi, S.H. Diverse deep-sea fungi from the South China sea and their antimicrobial activity. Curr. Microbiol. 2013, 67, 525-530. [CrossRef]

46. Liu, Z.; Wang, Q.; Li, S.; Cui, H.; Sun, Z.; Chen, D.; Lu, Y.; Liu, H.; Zhang, W. Polypropionate Derivatives with Mycobacterium tuberculosis Protein Tyrosine Phosphatase B Inhibitory Activities from the Deep-Sea-Derived Fungus Aspergillus fischeri FS452. J. Nat. Prod. 2019, 82, 3440-3449. [CrossRef]

47. Fredimoses, M.; Zhou, X.; Lin, X.; Tian, X.; Ai, W.; Wang, J.; Liao, S.; Liu, J.; Yang, B.; Yang, X.; et al. New prenylxanthones from the deep-sea derived fungus Emericella sp. SCSIO 05240. Mar. Drugs 2014, 12, 3190-3202. [CrossRef]

48. Li, X.D.; Xu, G.M.; Zhang, P.; Wang, B.G. Antimicrobial Phenolic Bisabolanes and Related Derivatives from Penicillium aculeatum SD-321, a Deep Sea Sediment-Derived Fungus. J. Nat. Prod. 2015, 78, 844-849. [CrossRef]

49. Guo, W.; Zhang, Z.; Zhu, T.; Gu, Q.; Li, D. Penicyclones A-E, Antibacterial Polyketides from the Deep-Sea-Derived Fungus Penicillium sp. F23-2. J. Nat. Prod. 2015, 78, 2699-2703. [CrossRef] [PubMed]

50. Niu, S.; Si, L.; Liu, D.; Zhou, A.; Zhang, Z.; Shao, Z.; Wang, S.; Zhang, L.; Zhou, D.; Lin, W. Spiromastilactones: A new class of influenza virus inhibitors from deep-sea fungus. Eur. J. Med. Chem. 2016, 108, 229-244. [CrossRef]

51. Liang, X.; Nong, X.H.; Huang, Z.H.; Qi, S.H. Antifungal and Antiviral Cyclic Peptides from the Deep-Sea-Derived Fungus Simplicillium obclavatum EIODSF 020. J. Agric. Food Chem. 2017, 65, 5114-5121. [CrossRef] [PubMed]

52. Cheng, Z.; Zhao, J.; Liu, D.; Proksch, P.; Zhao, Z.; Lin, W. Eremophilane-Type Sesquiterpenoids from an Acremonium sp. Fungus Isolated from Deep-Sea Sediments. J. Nat. Prod. 2016, 79, 1035-1047. [CrossRef] [PubMed]

53. Niu, S.; Liu, D.; Shao, Z.; Proksch, P.; Lin, W. Eremophilane-type sesquiterpenoids in a deep-sea fungus Eutypella sp. activated by chemical epigenetic manipulation. Tetrahedron 2018, 74, 7310-7325. [CrossRef]

54. Chen, S.; Wang, J.; Lin, X.; Zhao, B.; Wei, X.; Li, G.; Kaliaperumal, K.; Liao, S.; Yang, B.; Zhou, X.; et al. Chrysamides A-C, Three Dimeric Nitrophenyl trans-Epoxyamides Produced by the Deep-Sea-Derived Fungus Penicillium chrysogenum SCSIO41001. Org. Lett. 2016, 18, 3650-3653. [CrossRef] [PubMed] 
55. Lu, X.; He, J.; Wu, Y.; Du, N.; Li, X.; Ju, J.; Hu, Z.; Umezawa, K.; Wang, L. Isolation and Characterization of New Anti-Inflammatory and Antioxidant Components from Deep Marine-Derived Fungus Myrothecium sp. Bzo-1062. Mar. Drugs 2020, 18, 597. [CrossRef] [PubMed]

56. Wang, L.; Li, M.; Lin, Y.; Du, S.; Liu, Z.; Ju, J.; Suzuki, H.; Sawada, M.; Umezawa, K. Inhibition of cellular inflammatory mediator production and amelioration of learning deficit in flies by deep sea Aspergillus-derived cyclopenin. J. Antibiot. 2020, 73, 622-629. [CrossRef] [PubMed]

57. Wang, Y.N.; Meng, L.H.; Wang, B.G. Progress in Research on Bioactive Secondary Metabolites from Deep-Sea Derived Microorganisms. Mar. Drugs 2020, 18, 614. [CrossRef] [PubMed]

58. Sohn, J.H.; Lee, Y.R.; Lee, D.S.; Kim, Y.C.; Oh, H. PTP1B inhibitory secondary metabolites from marine-derived fungal strains Penicillium spp. And Eurotium sp. J. Microbiol. Biotechnol. 2013, 23, 1206-1211. [CrossRef]

59. Niu, S.; Liu, Q.; Xia, J.M.; Xie, C.L.; Luo, Z.H.; Shao, Z.; Liu, G.; Yang, X.W. Polyketides from the Deep-Sea-Derived Fungus Graphostroma sp. MCCC 3A00421 Showed Potent Antifood Allergic Activities. J. Agric. Food Chem. 2018, 66, 1369-1376. [CrossRef]

60. Niu, S.; Fan, Z.W.; Xie, C.L.; Liu, Q.; Luo, Z.H.; Liu, G.; Yang, X.W. Spirograterpene A, a Tetracyclic Spiro-Diterpene with a Fused 5/5/5/5 Ring System from the Deep-Sea-Derived Fungus Penicillium granulatum MCCC 3A00475. J. Nat. Prod. 2017, 80, 2174-2177. [CrossRef]

61. Han, W.; Cai, J.; Zhong, W.; Xu, G.; Wang, F.; Tian, X.; Zhou, X.; Liu, Q.; Liu, Y.; Wang, J. Protein tyrosine phosphatase 1B (PTP1B) inhibitors from the deep-sea fungus Penicillium chrysogenum SCSIO 07007. Bioorg. Chem. 2020, 96, 103646. [CrossRef]

62. Yao, Q.; Wang, J.; Zhang, X.; Nong, X.; Xu, X.; Qi, S. Cytotoxic Polyketides from the Deep-Sea-Derived Fungus Engyodontium album DFFSCS021. Mar. Drugs 2014, 12, 5902-5915. [CrossRef]

63. Wang, F.Z.; Huang, Z.; Shi, X.F.; Chen, Y.C.; Zhang, W.M.; Tian, X.P.; Li, J.; Zhang, S. Cytotoxic indole diketopiperazines from the deep sea-derived fungus Acrostalagmus luteoalbus SCSIO F457. Bioorg. Med. Chem. Lett. 2012, 22, 7265-7267. [CrossRef]

64. Cai, S.; Zhu, T.; Du, L.; Zhao, B.; Li, D.; Gu, Q. Sterigmatocystins from the deep-sea-derived fungus Aspergillus versicolor. J. Antibiot. 2011, 64, 193-196. [CrossRef]

65. Li, Y.; Ye, D.; Shao, Z.; Cui, C.; Che, Y. A sterol and spiroditerpenoids from a Penicillium sp. isolated from a deep sea sediment sample. Mar. Drugs 2012, 10, 497-508. [CrossRef] [PubMed]

66. Lin, X.; Zhou, X.; Wang, F.; Liu, K.; Yang, B.; Yang, X.; Peng, Y.; Liu, J.; Ren, Z.; Liu, Y. A new cytotoxic sesquiterpene quinone produced by Penicillium sp. F00120 isolated from a deep sea sediment sample. Mar. Drugs 2012, 10, 106-115. [CrossRef]

67. Guo, W.; Peng, J.; Zhu, T.; Gu, Q.; Keyzers, R.A.; Li, D. Sorbicillamines A-E, nitrogen-containing sorbicillinoids from the deep-sea-derived fungus Penicillium sp. F23-2. J. Nat. Prod. 2013, 76, 2106-2112. [CrossRef]

68. Lauritano, C.; Andersen, J.H.; Hansen, E.; Albrigtsen, M.; Escalera, L.; Esposito, F.; Helland, K.; Hanssen, K.; Romano, G.; Ianora, A. Bioactivity Screening of Microalgae for Antioxidant, Anti-Inflammatory, Anticancer, Anti-Diabetes, and Antibacterial Activities. Front. Mar. Sci. 2016, 3, 68. [CrossRef]

69. Li, Y.; Ye, D.; Chen, X.; Lu, X.; Shao, Z.; Zhang, H.; Che, Y. Breviane spiroditerpenoids from an extreme-tolerant Penicillium sp. isolated from a deep sea sediment sample. J. Nat. Prod. 2009, 72, 912-916. [CrossRef]

70. Kawabata, T.; Lindsay, D.J.; Kitamura, M.; Konishi, S.; Nishikawa, J.; Nishida, S.; Kamio, M.; Nagai, H. Evaluation of the bioactivities of water-soluble extracts from twelve deep-sea jellyfish species. Fish. Sci. 2013, 79, 487-494. [CrossRef]

71. Blunt, J.W.; Copp, B.R.; Keyzers, R.A.; Munro, M.H.G.; Prinsep, M.R. Marine natural products. Nat. Prod. Rep. 2015 , 32, 116-211. [CrossRef]

72. Newman, D.J.; Cragg, G.M. Natural products as sources of new drugs over the 30 years from 1981 to 2010. J. Nat. Prod. 2012, 75, 311-335. [CrossRef]

73. Hitora, Y.; Takada, K.; Okada, S.; Ise, Y.; Matsunaga, S. (-)-Duryne and its homologues, cytotoxic acetylenes from a marine sponge Petrosia sp. J. Nat. Prod. 2011, 74, 1262-1267. [CrossRef]

74. Desoubzdanne, D.; Marcourt, L.; Raux, R.; Chevalley, S.; Dorin, D.; Doerig, C.; Valentin, A.; Ausseil, F.; Debitus, C. Alisiaquinones and Alisiaquinol, dual inhibitors of Plasmodium falciparum enzyme targets from a new caledonian deep water sponge. J. Nat. Prod. 2008, 71, 1189-1192. [CrossRef]

75. Paterson, I.; Dalby, S.M.; Roberts, J.C.; Naylor, G.J.; Guzmun, E.A.; Isbrucker, R.; Pitts, T.P.; Linley, P.; Divlianska, D.; Reed, J.K.; et al. Leiodermatolide, a Potent Antimitotic Macrolide from the Marine Sponge Leiodermatium sp. Angew. Chem. 2011, 123, 3277-3281. [CrossRef]

76. Na, M.; Ding, Y.; Wang, B.; Tekwani, B.L.; Schinazi, R.F.; Franzblau, S.; Kelly, M.; Stone, R.; Li, X.C.; Ferreira, D.; et al. Anti-infective discorhabdins from a deep-water alaskan sponge of the genus Latrunculia. J. Nat. Prod. 2010, 73, 383-387. [CrossRef]

77. Lauritano, C.; Martínez, K.A.; Battaglia, P.; Granata, A.; de la Cruz, M.; Cautain, B.; Martín, J.; Reyes, F.; Ianora, A.; Guglielmo, L. First evidence of anticancer and antimicrobial activity in Mediterranean mesopelagic species. Sci. Rep. 2020, 10, 4929. [CrossRef]

78. Appleton, D.R.; Chuen, C.S.; Berridge, M.V.; Webb, V.L.; Copp, B.R. Rossinones A and B, biologically active meroterpenoids from the antarctic ascidian, Aplidium species. J. Org. Chem. 2009, 74, 9195-9198. [CrossRef]

79. Wangun, H.V.; Wood, A.; Fiorilla, C.; Reed, J.K.; McCarthy, P.J.; Wright, A.E. Gymnochromes e and F, Cytotoxic Phenanthroperylenequinones from a Deep-Water Crinoid, Holopus rangii. J. Nat. Prod. 2010, 73, 712-715. [CrossRef]

80. Andrianasolo, E.H.; Haramaty, L.; McPhail, K.L.; White, E.; Vetriani, C.; Falkowski, P.; Lutz, R. Bathymodiolamides A and B, ceramide derivatives from a deep-sea hydrothermal vent invertebrate mussel, Bathymodiolus thermophilus. J. Nat. Prod. 2011, 74, 842-846. [CrossRef] 